\title{
Evaluation of Antioxidant Efficiency of Croton tiglium L. Seeds Extracts after Incorporating Silver Nanoparticles
}

\author{
Wael Mahmoud Aboulthana ${ }^{1}$, Ahmed M. Youssef ${ }^{2 *}$, Amal M. El-Feky ${ }^{3}$, Noha El- \\ Sayed Ibrahim ${ }^{4}$, Mohamed M. Seif', Amgad Kamal Hassan ${ }^{1}$ \\ ${ }^{1}$ Biochemistry Department, Genetic Engineering and Biotechnology Division, \\ National Research Centre, Dokki, Giza, Egypt (Affiliation ID: 60014618). \\ ${ }^{2}$ Packaging Materials Department, National Research Center, Dokki, Giza, Egypt \\ (Affiliation ID: 60014618). \\ ${ }^{3}$ Pharmacognosy Department, Pharmaceutical and Drug Industries Research \\ Division, National Research Centre, Dokki, Giza, Egypt (Affiliation ID: 60014618). \\ ${ }^{4}$ Microbial Biotechnology Department, Genetic Engineering and Biotechnology \\ Division, National Research Centre, Dokki, Giza, Egypt (Affiliation ID: 60014618). \\ ${ }^{5}$ Toxicology and Food contaminants, Food Industry and Nutrition Division, National \\ Research Center, Dokki, Giza, Egypt (Affiliation ID: 60014618).
}

\begin{abstract}
$\mathbf{T}$ HIS STUDY aimed to enhance efficiency of the different Croton tiglium (C. tiglium) seeds extracts by incorporation of silver nanoparticles (Ag-NPs) through raised up cytotoxicity against growth of human colon cancer cells. C. tiglium seeds contain various phytoconstituents e.g., carbohydrates (glycosides), flavonoids, sterols (triterpenes), alkaloids and proteins. The protein was hydrolyzed in the dried aqueous seeds extract into free amino acids, the essential amino acids $(20.71 \%)$ \& nonessential amino acids (79.29\%). Furthermore, the mucilage in the dried aqueous seeds extract and the lipoidal contents in the saponifiable matter of the petroleum ether extract were represented by total identified sugars represent $\sim 81.21 \%$ of the total mucilage hydrolyzate. The lipoidal contents in the saponifiable matter of the petroleum ether extract were represented by total saturated fatty acids (13.68\%), total monoenoic fatty acids (34.49\%), total dienoic fatty acids (45.76\%) and total identified fatty acids $(93.93 \%)$.
\end{abstract}

Moreover, the unsaponifiable matter was represented by saturated hydrocarbons $(40.73 \%)$, unsaturated hydrocarbons $(18.93 \%)$, fatty alcohols $(10.08 \%)$, sterols $(10.61 \%)$ and total identified compounds $(80.35 \%)$. In addition, there were four compounds ( $\beta$ sitosterol, $\alpha$-amyrin, Oleanolic acid and 3-O- $\beta$-D-glucopyranosyl- $\beta$-sitosterol (daucosterol)) isolated from the petroleum ether extract. Additionally, incorporation of Ag-NPs into the extract caused no toxicity on the experimental animals when administrated orally. It was found that the median lethal dose $\left(\mathrm{LD}_{50}\right)$ of the ethanolic, petroleum ether and aqueous seeds extract- $\mathrm{Ag}$ nanocomposites was about 7.95, 5.2 and $65 \mathrm{ml} / \mathrm{Kg}$, respectively.

Keywords: Croton tiglium L. Seeds, Silver nanoparticles, Polyphenols, Scavenging activity, Anticancer activity.

\section{Introduction}

Croton tiglium L. belongs to the family Euphorbiaceae that occur in tropical and temperate regions all over the world and includes about 280 genera and 8000 species which occur in tropical and temperate regions all over the world [1]. It is widely used in ethnomedicine for the treatment of several cancer diseases [2]. Seeds, leaves, bark and root of $C$. tiglium are used in traditional medicine for treatment of constipation, dyspepsia, dysenteriae, gastrointestinal disorders, intestinal inflammation, rheumatism, peptic ulcer, visceral pain, headache, purgative, colds, fever, worms, ascities and intracranial hemorrhage and in snake poisoning[3-5]. It was reported that C. tiglium seeds are well-known by its toxicity (severe purgative action). This because the seeds oil contains phorbol esters and crotonic acid along with the fatty acids in addition to presence of the active phytoconstituents. These constituents are oil soluble and it is necessary to remove of

*Corresponding author e-mail: amyoussef27@yahoo.com; Tel/ Fax, (202) 33322418 (202) 33370931

DOI: 10.21608/EJCHEM.2018.4960.1442

(C)2017 National Information and Documentation Center (NIDOC) 
reduce level of these constituents to reduce the C. tiglium seeds toxicity during the purification process [6-8].

An attempt was made by High-performance liquid chromatography (HPLC) for identification and quantification of the toxic principles along with other physiochemical parameters and responsible for the severe purgative action of C. tiglium seeds [7]. Moreover, the ethanolic seed extract of $C$. tiglium exhibited strong antidermatophytic activities. It was found that crude extracts from these plant seeds were active against Trichocomaceae (Aspergillusniger and A. tamarii) and Mucoraceae (Mucormucedo and Rhizopussolani) [9]. Thereafter, the ethanolic seeds extract of $C$. tiglium exhibited atopical application on treating skin fungal infection and formulation of the extracts into shampoo or soap [10].

It was postulated that $C$. tiglium seeds extract exhibited high antioxidant activity due to the presence of some other phytochemicals such as ascorbic acid, tocopherol and other pigments [11]. 12-O-tetradecanoylphorbol-13-acetate is major active constituent in the croton oil which was isolated from seeds of this plant. It is used for treatment of the solid tumors due to its ability to inhibit the growth, stimulate apoptosis in prostate, breast, colon and lung cancer diseases [12]. In 2014, Yumnamcha et al. [13] emphasized that aqueous $C$. tiglium seeds extract cause increase plasmid DNA strand breakage in a dose dependent manner. They found that it is necessary for the plant extract need to be evaluated before it could be used for therapeutic purposes. The recent study showed that $C$. tiglium seeds extracts have no significant alterations in the biochemical measurements but they have little effect on some haematological indices [14].

Development of polymer-metal nanocomposites containing metal nanoparticles (MNPs) is considered to be one of the most promising solutions to their inherent stability problem. Incorporation of MNPs into polymeric matrices showed valuable properties in many practical applications [15-19]. Synthesis of silver nanoparticles (Ag-NPs) by reduction of aqueous silver nitrate into Ag-NPs during exposure to plant extracts can be easily monitored by using UV-visible spectrophotometer [20]. The plant extracts with Ag-NPs exhibited good antioxidant activity at lower concentrations [21]. Recently, it was found that incorporation of Ag-NPs in the plant extract increased the total phenolic compounds and total flavonoids. It was found that plant Ag-NPs showed a higher antioxidant and antimicrobial activity compared to plant extract alone or silver nitrate [22].

The present study aimed to evaluate the phytochemical and biological efficiency of different $C$. tiglium seeds extracts. Consequently, efficiency of the different extracts was studied after incorporation of the nanoparticles.

\section{Materials and Methods}

\section{Preparation of the plant materials}

The dried C. tiglium seeds were obtained from Agricultural Research Center, Giza, Egypt and dried in an incubator at $50{ }^{\circ} \mathrm{C}$ for $72 \mathrm{hrs}$. The dried seeds were crushed into powder in an electric blender.

Pharmacopoeial constituents and vitamins (fat and water soluble)

Moisture content was determined by heating finely powdered seeds of $C$. tiglium in the oven at $105^{\circ} \mathrm{C}$ for $3 \mathrm{hrs}$. Furthermore, the ashes contents (total, water soluble and acid-insoluble ashes) were assayed in the powdered seeds by method suggested by Kirk and Sawyer [23]. Fat and water soluble vitamins were analyzed according to method suggested by Hasan et al. [24] using High Performance Liquid Chromatographic system (Shimadzu-UFLC Prominence), equipped with an auto sampler (Model-SIL 20AC HT) and UVVisible detector (Model-SPD 20A).

\section{Preliminary phytochemical screening tests}

Wide range of the common phytoconstituents was determined in the plant seeds according to recommended and referenced methods. These constituents were represented by carbohydrates and /or glycosides [25], free and combined flavonoids [26], coumarins, saponins, alkaloids, nitrogenous compounds, sterols and /or triterpenes [27], tannins [28], proteins [29] and anthraquinones [30].

Preparation of different $C$. tiglium seeds extracts for phytochemical studies

Preparation of alcoholic extract

The powdered seeds had been extracted by cold maceration in successive portions of $80 \%$ ethyl alcohol at room temperature (cold maceration). The extraction mixture was filtered through a Whatman No. 1 filter paper and then concentrated to dryness in a rotary evaporator at $45^{\circ} \mathrm{C}$ under reduced pressure. 


\section{Preparation of petroleum ether extract}

The dried seeds powder had been separately extracted with petroleum ether $\left(60-80^{\circ} \mathrm{C}\right)$. The extract was separately filtered through a Whatman No. 1 filter paper, and then concentrated to dryness in a rotary evaporator at $45^{\circ} \mathrm{C}$ under reduced pressure.

\section{Preparation of aqueous extract}

The dried powdered seeds have been extracted by distilled water. The extract was separately filtered through a Whatman No. 1 filter paper, and then concentrated to dryness in a rotary evaporator at $50^{\circ} \mathrm{C}$ under reduced pressure.

\section{Chromatographic analysis of total phenolics}

The different phenolic compounds were identified by high pressure liquid chromatograpahy (HPLC) (Shimadzu-UFLC Prominence). This technique is consisting of two units. One is responsible for separation of the compounds according to the difference in polarity and the other is responsible for detection of these compounds. It is equipped with an auto sampler (Model-SIL 20AC HT) and UV-Visible detector (Model-SPD 20A) (Japan). The separation process was carried out through analytical column of an Eclipse XDB-C18 (150 X $4.6 \mu \mathrm{m}$; $5 \mu \mathrm{m}$ ) with a C18 guard column (Phenomenex, Torrance, CA). The mobile phase is consisting of solvent system of acetonitrile (solvent A) and $2 \%$ acetic acid in water $(\mathrm{v} / \mathrm{v})$ (solvent $\mathrm{B})$. Before the chromatographic run, all samples were filtered through a $0.45 \mu \mathrm{m}$ Acrodisc syringe filter (Gelman Laboratory, MI). Fifty micro litre (50 $\mu \mathrm{l})$ from each extract (alcoholic and water aqueous) was injected automatically by the injector piece. The flow rate was kept at $0.8 \mathrm{~m} \cdot \mathrm{min}^{-1}$ for a total run time of $70 \mathrm{~min}$ and the gradient program was as follows: $100 \% \mathrm{~B}$ to $85 \% \mathrm{~B}$ in $30 \mathrm{~min}, 85 \% \mathrm{~B}$ to $50 \% \mathrm{~B}$ in $20 \mathrm{~min}, 50 \% \mathrm{~B}$ to $0 \% \mathrm{~B}$ in $5 \mathrm{~min}$ and $0 \%$ $\mathrm{B}$ to $100 \% \mathrm{~B}$ in $5 \mathrm{~min}$. The peaks were monitored simultaneously at 280 and $320 \mathrm{~nm}$ for the benzoic acid and cinnamic acid derivatives, respectively. When the chromatographic run was finished, the peaks were identified by congruent retention times and UV spectra and compared with those of the standards.

In the dried aqueous extract, total carbohydrate content was quantified as glucose by phenol sulphuric acid method [31]. Consequently, the mucilagehas been separately isolated [32] then identified separately through specific testes [33, 34]. Furthermore, the Mucilage was hydrolyzed and purified according method of Chrums and
Stephen [35]. The polysaccharides were analyzed in the hydrolysate using Gas Liquid Chromatography (GLC) (model HP 6890) equipped with flame ionization detector at $270^{\circ} \mathrm{C}$. The analysis was carried out using ZB- 1701 column $(30 \mathrm{~m} \times 0.25 \mathrm{~m} \times 0.25 \mu \mathrm{m})$, $14 \%$ cyanopropyl phenyl methyl, the carrier gas is helium at flow rate of $1.2 \mathrm{ml} / \mathrm{min}$ under pressure $10.6 \mathrm{psi}$ and velocity of $41 \mathrm{~cm} / \mathrm{sec}$. The injector chamber temperature was $-250^{\circ} \mathrm{C}$. Quantitative determination was based on peak area measurement while qualitative identification was carried out by comparison of the retention times of the peaks with those of the authentic sugars.

In addition, the total protein content has been estimated by determining the nitrogen content using micro-kjeldahl method suggested by Pearson [36] using Markham distillation apparatus. The proteins were isolated, for isolation and purification of the polypeptides according to method described by El-Gengaihi et al. [37]. The dried crude polypeptides have been separately dialyzed by membrane (dialysis bag) and the non-dialyzable fraction was collected and dried. Consequently, the polypeptides were hydrolyzed into amino acids that have been separated by HPLC then analyzed by amino acid analyzer (model Eppendorf-Germany LC 3000) according to method suggested by Widner and Eggum [38].

In the petroleum ether extract, the total steroidal and terpenoidal contents were estimated quantitatively by the spectrophotometric method which is based on measuring intensity of the color developed when sterols and triterpenes react with Lieberman-Burchard reagent. Percentages of steroidal and terpenoidal have been calculated as $\beta$-sitosterol and $\beta$-amyrin, respectively with reference to a pre-established standard calibration curve [39]. The extract residues were saponified and concentrated according to method suggested by Tsuda et al. [40].

Moreover, the total free fatty acid content was liberated from the unsaponifiable matter then quantified. The fatty acids in the residue were converted into the methyl ester form based on method suggested by Finar [41]. Consequently, the fatty acid methyl esters and unsaponifiable matter were subjected to gas chromatograph coupled with a mass spectrometer (model Shimadzu GC/MS-QP5050A). The constituents have been identified by comparison of their spectral fragmentation patterns with those of the available database libraries Wiley (Wiley Int.) USA and NIST (Nat. Inst. St. Technol., USA) and/ 
or published data [42]. Quantitative determination was carried out based on peak area integration.

The dried petroleum ether extract was submitted to top of a column packed with $175 \mathrm{~g}$ activated silica $(120 \mathrm{~cm}$ height $\times 2.5 \mathrm{~cm}$ i.d.). Elution was successively carried out by different ratios of petroleum ether $\left(60-80^{\circ} \mathrm{C}\right)$ and chloroform with increasing polarity. The fractions were successively collected and concentrated then screened by thin layer chromatography (TLC) using benzene: ethyl acetate (8:2) as solvent system. The TLC plates were examined under UV-254 $\mathrm{nm}$ and visualized. The similar fractions were combined then evaporated under reduced pressure at a temperature not exceeding $40^{\circ} \mathrm{C}$. Thereafter, the isolated compounds were subjected to physical, chemical, chromatographic and spectral analyses (UV, MS, IR, ${ }^{1} \mathrm{H}$ and ${ }^{13} \mathrm{C}$ NMR) as well as comparison with the available reference standards and available published data.

Preparation of C. tiglium seeds extracts silver nanocomposites

The Ag-NPs were prepared through reducing silver nitrate $\left(\mathrm{AgNO}_{3}\right)$ with ethylene glycol (EG) in the existence of polyol. In a classic method, 10 $\mathrm{mL}$ of EG were refluxed at $160{ }^{\circ} \mathrm{C}$ for $25 \mathrm{~min}$. Then, $5 \mathrm{~mL}$ solution of $\mathrm{AgNO}_{3}$ in $\mathrm{EG}$ and $10 \mathrm{~mL}$ solution of $0.15 \mathrm{M}$ PVP in EG containing $0.03 \mathrm{mM}$ $\mathrm{MnCl}_{2}$ were concurrently injected into the flask over a period of $10 \mathrm{~min}$, the reaction mixture was further refluxed and vigorously stirred at $160{ }^{\circ} \mathrm{C}$ for $60 \mathrm{~min}$. The reaction mixture was then cooled to room temperature. The product was centrifuged at $3000 \mathrm{rpm}$ for $5 \mathrm{~min}$, and then washed with acetone and ethanol for three times. The Ag-NPs were collected and dried in oven at $70{ }^{\circ} \mathrm{C}$ then the Ag-NPs were added to the $C$. tiglium seeds extracts by different concentrations to form $C$. tiglium seeds extracts silver nanocomposites.

In vitro antioxidant and cytotoxic activities of the different extracts

Total polyphenolic compounds

The total polyphenolic compounds were estimated in the different $C$. tiglium seeds extracts before and after incorporation of silver nanoparticles according to Singleton and Rossi [43] by using folin ciocalteu reagent purchased from Sigma Chemicals Co. Concentration of the total polyphenols was calculated as a gallic acid equivalent from the calibration curve of gallic acid standard solutions obtained from Sigma Chemicals Co. covering the concentration range between 0.2 and $1.0 \mathrm{mg} / \mathrm{ml}$.

\section{Total antioxidant capacity}

Total antioxidant capacity of extract was evaluated through the assay of the green phosphate/ $\mathrm{Mo}^{5+}$ complex according to the method described by Prieto et al. [44]. Antioxidant capacity was expressed as mg gallic acid equivalent per gram dry weight.

\section{Total reducing power}

The total reducing power was determined according to method suggested by Oyaizu [45]. The absorbance was measured at $700 \mathrm{~nm}$ against blank prepared without adding extract. Ascorbic acid at various concentrations was used as standard. A high absorbance of the reaction mixture at $700 \mathrm{~nm}$ indicates a higher reducing power.

\section{Free radical scavenging activity}

\section{DPPH radical-scavenging activity}

Percentage of the antioxidant activity was evaluated by method described by BrandWilliams et al. [46] using DPPH (2,2-diphenyl-1picryl-hydrazyl-hydrate) for initiation of the free radicals and absorbance of the resulting solution was measured spectrophotometrically at $517 \mathrm{~nm}$.

\section{ABTS radical scavenging assay}

For 2, 2'-azinobis-(3- ethylbenzothiazoline6-sulfonic acid) (ABTS) assay, the procedure followed the method suggested by Arnao et al. [47] with some modifications. The extracts were allowed to react with ABTS solution and the absorbance was taken at $734 \mathrm{~nm}$ after $7 \mathrm{~min}$ using a spectrophotometer. The ABTS scavenging capacity of the extract was compared with that of ascorbic acid.

\section{Anticancer activity}

Cytotoxic activity test (In vitro bioassay on human tumor cell lines) was conducted and determined. It was performed on human colon carcinoma cell line according to protocol suggested by Vichai and Kirtikara [48].

\section{Characterization of the prepared Ag-NPs \\ $X$-ray diffraction (XRD)}

The crystal structure of the filler powders was determined using a Philips X-ray diffractometer (PW 1930 generator, PW 1820 goniometer) equipped with $\mathrm{Cu} \mathrm{K \alpha}$ radiation $(45 \mathrm{kV}, 40 \mathrm{~mA}$, with $\lambda=0.15418 \mathrm{~nm}$ ). The scans of the analysis were run in $2 \theta$ range of 5 to $80^{\circ}$ with step size of 0.02 and step time of $1 \mathrm{~s}$.

\section{Transmission Electron Microscope (TEM)}

The morphological and particles size of 
prepared samples were demonstrated by using TEM model JEM-1230, Japan, operated at 120 $\mathrm{kV}$, with maximum magnification of $600 \times 10^{3}$ and a resolution until $0.2 \mathrm{~nm}$. A drop of an aqueous dispersion of the prepared samples was placed on a carbon-coated copper grid and allowed to dry in air before characterization.

$U V$-spectroscopy of the prepared $\mathrm{Ag}$-NPs

UV-spectroscopy was carried by Shimadzu UV-Vis recording spectrophotometer UV-240.

\section{DLS measurements}

Particle size distribution was measured using Particle Sizing Systems, Inc. Santa Barbara, Calif., USA.

\section{Experimental}

\section{Ethical Statement}

The experimental design and animal handling were performed according to the experimental protocol which was approved by Institutional Animal Ethics Committee of National Research Centre, Dokki, Giza, Egypt and were conducted in accordance with guidelines as per "Guide for the care and use of laboratory animal" and with permission from Committee for the Purpose of Control and Supervision of Experiments on Animals.

\section{Median lethal dose of different extracts (LD50)}

The different $C$. tiglium seeds extracts (after incorporation of Ag-NPs) were evaluated separately after calculating the $\mathrm{LD}_{50}$. Two hundred and forty adult albino mice (weight 20-25 g) were used to study acute toxicity. Animals were divided into 10 groups ( 8 mice in each group) for each extract. The groups were treated orally by stomach tube with rising doses of $0.2,0.4,0.6,0.8,1.0$, $1.2,1.4,1.6,1.8$ and $2.0 \mathrm{ml} /$ mice of extract- $\mathrm{Ag}$ nanocomposites. Mortality was recorded after 24 hrs of extract treatment. The $\mathrm{LD}_{50}$ was calculated for each extract-Ag nanocomposites using equation suggested by Paget and Barnes [49].

\section{Result and Discussion}

Evaluation of phytochemical and physicochemical properties of C. tiglium seeds

The phytochemical and physico-chemical evaluation of $C$. tiglium seeds provide useful information to verify the pharmacognostical identity of seeds of this plant and to carry phytochemical and physicochemical investigations of these seeds [50].

Table 1 revealed data of the physiochemical parameters (moisture, total ash content, watersoluble ash and acid insoluble ash) which determined in the dried $C$. tiglium seeds powders following procedure of the Egyptian pharmacopoeia. These constants could be used as significant criteria for the identity and purity of these plant seeds. Elevation of the ash contents during the purification process might be attributable to loss of oil soluble constituents in the plant seeds [51].

Working with crude extracts, means working with complex mixtures of biologically active compounds, some of the compounds in such a mixture can be genotoxic or antigenotoxic [13]. For this reason, it is necessary to undergo phytochemical screening to predict the potential health hazards occurred as a result of using the plant for medicinal purposes. Phytochemical constituents are non-nutrient, bioactive, secondary metabolites, naturally occurring plant compounds present in C. tiglium seeds and are considerably diverse [52].

Phytochemical screening of C. tiglium seeds

These constituents are commonly used for medicinal purposes as analgesic, antimalarial, bactericidal and antiseptic [53]. In the present study, the air-dried C. tiglium seeds powder subjected to the phytochemical screening tests for the detection of various bioactive compounds using chemical methods. As illustrated in Table 2, the air-dried seeds powders contain various phytoconstituents such as carbohydrates (glycosides), flavonoids, sterols (triterpenes), alkaloids (nitrogenous compounds) and proteins. This was in accordance with the study documented by Lopes et al. [54]. It was speculated that certain saponin mixture and alkaloids might be responsible for the genotoxic effects of $C$. tiglium seeds.

It was reported that certain group of bioactive compound like alkaloids and saponin mixtures are responsible for the DNA damage [55]. Further studies with more advanced practical techniques are required for confirming the genotoxic potential of C. tiglium seeds. Moreover, Salatino et al. [52] reported that terpenoids are the predominant secondary metabolite constituents in seeds of this plant. Triterpenoids, either pentacyclic or steroidal, have frequently been reported for seeds of Croton species. From medicinal point of view, all the seeds extracts revealed the presence of alkaloids, flavonoids, terpenoids, cardiac glycosides, tannins, glycoside and saponins which are considered very important components [56]. 
TABLE 1. Percentages of certain pharmacopoeial constants of $C$. tiglium seeds.

\begin{tabular}{cccc}
\hline \multicolumn{3}{c}{ Pharmacopoeial constants (\%) } \\
\hline Moisture & Total Ash & Water soluble ash & Acid insoluble ash \\
\hline 7.5 & 15 & 8.6 & 5.7 \\
\hline
\end{tabular}

TABLE 2. Phytoconstituents of $C$. tiglium seeds.

\begin{tabular}{cc} 
Constituent & Result \\
\hline Carbohydrates (Glycosides) & ++ \\
Flavonoids & + \\
Saponins & - \\
Tannins & ++ \\
Sterols (Triterpenes) & + \\
Alkaloids (Nitrogenous compounds) & + \\
Proteins & -
\end{tabular}

(-): Absent, (+): Present, (++): Appreciably present.

Presence of carbohydrate in the seeds extract could be a good source of energy [57]. Also, presence of tannins and alkaloids in C. tiglium seeds with high quantity may be responsible for antiemetic activity. Saponins are responsible for antibiotic activity in addition to its potential efficiency to inhibit growth of cancer cells [58, 59]. Flavonoids play a vital role against inflammation, platelet aggregation, allergies and microbial infection [60].

Study the physical and chemical characters of the C. tiglium seeds

As presented in Table 3, it was found that the highest yield was obtained in petroleum ether extract which appeared oily yellowish brown extract before incorporation of Ag-NPs, this because the $C$. tiglium seeds could be a good source of fixed oil and essential fatty acids [57]. Also, petroleum ether extract contains the highest amount of sterol. This finding was supported by the study carried out by Lan et al. [61] who reported that the oil obtained by extracting of the $C$. tiglium seeds with petroleum ether was subjected to methyl-esterification or dilution with ethyl ether. They postulated that the linoleic acid, oleic acid and eicosenoic acid were the main components which were identified in croton oil as a result of GC/MS analysis of in methyl-esterified samples in addition to the aromatic compounds (phorbol esters). Ganer et al. [50] emphasized that toxicity of $C$. tiglium seeds might refer to presence of oil soluble phorbol esters and crotonic acid in addition to the other constituents. During the purification process, the toxicity reduced through removal of these constituents. Thereafter, seeds of this plant became suitable for the therapeutic purposes.

Data compiled in Table 4 showed that $\alpha-\mathrm{E}$ and Vit. B1 are the most abundant fat and water soluble vitamins in C. tiglium seeds. Moreover, concentrations of Vit D3 and Vit B3 were too low to be detected. This was in accordance with Bello et al. [57] who mentioned during their study that the seeds could be good source of fat soluble vitamins.

HPLC Analysis of the free amino acids in the dried aqueous $C$. tiglium seeds extract

It was found that the dried aqueous $C$. tiglium seeds extract contains protein content representing about $25 \%$ (wt $/ w t)$ of the dried extract [38]. After isolation and purification processes, percent of the protein was about $23.5 \%$ (wt $/ \mathrm{wt}$ ) dried aqueous extract [37]. As presented in Table 5, there were eight essential and nine non-essential 
TABLE 3. Percentages, physical and chemical characters of the prepared $C$. tiglium seeds extracts.

\begin{tabular}{|c|c|c|c|}
\hline \multirow{2}{*}{ Character } & \multicolumn{3}{|c|}{ C. tiglium seeds extracts } \\
\hline & Ethyl alcohol & Petroleum ether & Aqueous \\
\hline Percentage (\%) & 31 & 45 & 23 \\
\hline \multicolumn{4}{|l|}{ Physical characters: } \\
\hline Color & Brown & Yellowish brown & Brown \\
\hline Condition & Semi-solid & Oily & Semi-solid \\
\hline \multicolumn{4}{|l|}{ Constituents: } \\
\hline Carbohydrates & + & - & + \\
\hline Flavonoids & + & - & + \\
\hline Saponins & - & - & - \\
\hline Tannins & - & - & - \\
\hline Sterols & + & ++ & - \\
\hline Alkaloids & + & - & + \\
\hline Proteins & + & - & + \\
\hline Anthraquinones & - & - & - \\
\hline
\end{tabular}

(-): Absent, (+): Present, (++): Appreciably present.

TABLE 4: Concentration of fat and water soluble vitamins in the dried powders of $C$. tiglium seeds.

\begin{tabular}{ccc}
\multicolumn{1}{c}{ Type of vitamin } & Concentration $(\boldsymbol{\mu g} / \mathbf{g})$ \\
\hline \multirow{2}{*}{ Fat soluble vitamins } & Vit A & 0.646 \\
& Vit D3 & ND \\
Water soluble vitamins & $\boldsymbol{\alpha}-\mathbf{E}$ & $\mathbf{9 . 4 9 5}$ \\
& B3 & ND \\
& B1 & $\mathbf{2 9 8 . 1 4 9}$ \\
& B6 & 0.288 \\
& B9 & 0.695 \\
& B2 & 1.328 \\
\hline
\end{tabular}

ND: Not detected concentration.

amino acids identified in the dried aqueous $C$. tiglium seeds extract representing about $20.71 \%$ $(\mathrm{wt} / \mathrm{wt})$ and $79.29 \%(\mathrm{wt} / \mathrm{wt})$ of the total amino acids, respectively. Moreover, it was found that isoleucine, methionine and phenyl alanine belong to the major essential amino acids representing about $4.74,3.84$ and $3.54 \%(\mathrm{wt} / \mathrm{wt})$ of the total amino acids content, respectively. However, proline and aspartic acid belong to the major nonessential amino acid and represent about 14.41 and $13.32 \%(\mathrm{wt} / \mathrm{wt})$ of the total amino acids content, respectively.
GLC analysis of mucilage after hydrolysis in the dried aqueous $C$. tiglium seeds extract

The carbohydrate content was estimated quantitatively in the dried aqueous C. tiglium seeds extract [25] and it was found that it represented about $16 \%(\mathrm{wt} / \mathrm{wt})$ of the dried aqueous extract [31. Based on the analysis suggested by Evan and Matz [33, 34], it was noticed that no gelatinous precipitate appeared upon the reaction with potassium hydroxide. In addition, the red stain obtained as a result of the reaction with ruthenium red indicates the mucilaginous nature with 
TABLE 5. HPLC Analysis of the free amino acids in the dried aqueous $C$. tiglium seeds extract.

\begin{tabular}{cccc}
\hline \multicolumn{3}{c}{ Total amino acids } \\
\hline Essential amino acids & \% of total amino acids & Non essential amino acids & \% of total amino acids \\
\hline Threonine & 1.59 & Aspartic acid & 13.32 \\
Valine & 2.42 & Serine & 11.30 \\
Methionine & 3.84 & Glutamic acid & 9.53 \\
Isoleucine & 4.74 & Glycine & 7.87 \\
Leucine & 1.63 & Proline & 14.41 \\
Phenyl alanine & 3.54 & Alanine & 4.02 \\
Lysine & 2.03 & Tyrosine & 10.85 \\
Tryptophan & 0.92 & Histidine & 4.74 \\
& 20.71 & Arginine & 3.25 \\
\hline
\end{tabular}

eliminating pectin. Furthermore, it was found the isolated mucilage expressed by $14.5 \%$ (wt/wt) of the dried aqueous extract. As compiled in Table 6, composition of the mucilage was determined qualitatively and quantitatively in the hydrolyzate by GLC.

$G C / M S$ analysis of the saponifiable matter in the petroleum ether C. tiglium seeds extract

The lipoidal matter was quantified spectrophotometrically in the petroleum ether C. tiglium seeds extract [39]. It was found that the total steroidal and terpenoidal contents were expressed by $12 \%$ and $24 \%$ of the dried extract as $\beta$-sitosterol and $\beta$-amyrin, respectively. Data compiled in Table 7 showed the methylated ester derivatives of fatty acids that were identified in the saponifiable matter of the petroleum ether $C$. tiglium seeds extract by GC/MS. It was revealed that eighteen compounds were identified representing about $93.93 \%$ of the total saponifiable matter. The saturated fatty acids constituted about $13.68 \%$, while the unsaturated fatty acids constituted $80.25 \%$. Furthermore, it was found that 11,14 -Octadecadienoic acid $(26.57 \%)$ was the major unsaturated fatty acid, while Hexadecanoic acid (6.64\%) was the major saturated fatty acid.

TABLE 6. GLC analysis of mucilage after hydrolysis in the dried aqueous $C$. tiglium seeds extract.

\begin{tabular}{ccc}
\hline Authentic sugars & R.T (min.) & \% of total mucilage hydrolyzate \\
\hline $\begin{array}{c}\text { Arabinose } \\
\text { Xylose }\end{array}$ & 8.31 & 23.38 \\
Ribose & 8.62 & 15.21 \\
Rhamnose & 8.97 & 11.84 \\
Galactose & 9.31 & 9.18 \\
Glucose & 13.29 & 13.15 \\
Total identified sugars & 14.38 & 8.45 \\
\hline
\end{tabular}

R.T: Retention time.

Egypt. J. Chem. 62, No. 2 (2019) 
TABLE 7. GC/MS analysis of the saponifiable matter in the petroleum ether $C$. tiglium seeds extract.

\begin{tabular}{|c|c|c|c|c|c|}
\hline $\mathbf{R t}$ & $\%$ & Fatty acid methyl ester & $\begin{array}{c}\text { Mol. } \\
\text { weight }\end{array}$ & $\begin{array}{l}\text { Base } \\
\text { peak }\end{array}$ & Other fragments \\
\hline 14.79 & 5.04 & 9-Tetradecenoic acid & 240 & 55 & $69,74,83,110,125,137,166,208$ \\
\hline 15.43 & 1.05 & 3-Methyl-tetradecanoic acid & 256 & 74 & $83,101,111,129,143,156,213,225,241$ \\
\hline 15.90 & 6.64 & Hexadecanoic acid & 270 & 74 & $87,97,129,143,199,227,239$ \\
\hline 17.64 & 1.04 & 3-Methyl-hexadecanoic acid & 284 & 74 & $\begin{array}{c}87,101,115,157,171,213,227,241 \\
253,270\end{array}$ \\
\hline 19.73 & 8.10 & 9,11-Octadecadienoic acid & 294 & 67 & $81,95,109,123,150,164,263$ \\
\hline 19.98 & 26.57 & 11,14-Octadecadienoic acid & 294 & 67 & $81,95,109,150,164,178,263$ \\
\hline 20.09 & 13.84 & 9-Octadecenoic acid & 296 & 55 & $\begin{array}{c}69,74,83,98,111,123,137,180,222, \\
264\end{array}$ \\
\hline 20.46 & 2.76 & Octadecanoic acid & 298 & 74 & $87,97,129,143,185,199,213,255$ \\
\hline 21.84 & 1.06 & Nonadecanoic acid & 312 & 74 & $\begin{array}{c}87,97,111,129,143,157,185,199,213, \\
269\end{array}$ \\
\hline 22.00 & 2.04 & 5-Eicosenoic acid & 324 & 55 & $\begin{array}{c}67,74,96,110,123,152,180,208,250 \\
275,292\end{array}$ \\
\hline 22.77 & 3.06 & 11-Docosenoic acid & 352 & 55 & $\begin{array}{c}69,74,83,97,123,152,180,208,236 \\
263,278,292\end{array}$ \\
\hline 23.24 & 0.09 & Docosanoic acid & 354 & 74 & 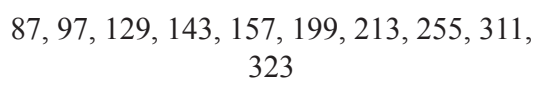 \\
\hline 23.95 & 4.26 & 15-Tetracosenoic acid & 380 & 55 & $\begin{array}{c}69,74,83,97,111,123,152,194,207 \\
222,250,264,277,291,306,348\end{array}$ \\
\hline 24.31 & 5.09 & 16-Pentacosenoic acid & 394 & 55 & $\begin{array}{c}69,74,83,97,111,125,152,194,222 \\
236,264,278,291,320,344,362\end{array}$ \\
\hline 24.68 & 1.04 & 24-Methyl-pentacosanoic acid & 410 & 74 & $\begin{array}{c}87,97,111,129,143,157,199,213,255 \\
269,311,325,353,367\end{array}$ \\
\hline 26.13 & 6.05 & 5,9-Heptacosadienoic acid & 420 & 81 & $\begin{array}{c}95,109,141,150,164,181,207,222 \\
278,346,371,388\end{array}$ \\
\hline 26.50 & 5.04 & 5,9-Octacosadienoic acid & 434 & 81 & $\begin{array}{c}95,109,141,150,163,181,207,236 \\
264,292,319,360,385,402\end{array}$ \\
\hline 28.86 & 1.16 & 19-Octacosenoic acid & 436 & 55 & $\begin{array}{c}69,74,83,97,111,125,152,194,222 \\
236,264,292,320,362,387,406\end{array}$ \\
\hline \multicolumn{6}{|c|}{ Total saturated fatty acids: $13.68 \%$} \\
\hline \multicolumn{6}{|c|}{ Total monoenoic fatty acids: $34.49 \%$} \\
\hline \multicolumn{6}{|c|}{ Total dienoic fatty acids: $45.76 \%$} \\
\hline Total id & tified $\mathrm{f}$ & $y$ acids: $93.93 \%$ & & & \\
\hline
\end{tabular}

Rt: Retention time 
GC/MS analysis of the unsaponifiable matter in the petroleum ether $C$. tiglium seeds extract

Table 8 displayed components of the unsaponifiable matter in the petroleum ether $C$. tiglium seeds extract by GC/MS. It was found that nineteen compounds were identified representing about $80.35 \%$ of the total unsaponifiable matter. In addition, n-Docosane $(14.42 \%)$ and 7-Phenyltridecane (9.10\%) were expressed as major compounds of the unsaponifiable matter.
During the present study, four compounds were isolated from the petroleum ether $C$. tiglium seeds extract and purified several times by preparative TLC using different developing solvent systems. Consequently, these isolated compounds were characterized with recording their $\mathrm{R}_{\mathrm{f}}$ values in benzene: ethyl acetate (8:2) accurately. All of the isolated compounds gave positive result with Lieberman-Burchard test indicating the presence of triterpenes and sterols [62]. Structures of these

TABLE 8. GC/MS analysis of the unsaponifiable matter in the petroleum ether $C$. tiglium seeds extract.

\begin{tabular}{|c|c|c|c|c|c|}
\hline Rt & $\%$ & Compound & $\begin{array}{c}\text { Mol. } \\
\text { weight }\end{array}$ & $\begin{array}{l}\text { Base } \\
\text { peak }\end{array}$ & Other fragments \\
\hline 9.71 & 0.50 & 2,3-Dimethylnonane & 156 & 57 & $43,71,83,112,141$ \\
\hline 11.96 & 0.61 & n-Dodecane & 170 & 57 & $43,71,85,99,113$ \\
\hline 18.78 & 0.97 & 2,6,11-Trimethyldodecane & 212 & 57 & $43,71,85,99,127,141,169$ \\
\hline 19.43 & 0.32 & 5-phenyl Decane & 218 & 91 & $105,119,147,161$ \\
\hline 21.23 & 0.70 & 2-phenyl Decane & 218 & 105 & $119,131,181$ \\
\hline 21.87 & 1.42 & 6-phenyl undecane & 232 & 91 & $105,119,161,189$ \\
\hline 21.98 & 4.00 & 6-phenyl dodecane & 246 & 91 & $105,119,147,189$ \\
\hline 22.26 & 3.20 & 1-Hexadecanol & 242 & 55 & $69,83,97,111,125,196,224$ \\
\hline 22.81 & 2.80 & 2-Phenyldodecane & 246 & 105 & $119,161,207,218$ \\
\hline 24.32 & 9.10 & 7-Phenyltridecane & 260 & 91 & $105,119,133,175,189$ \\
\hline 24.74 & 5.89 & 2-Phenyltridecane & 260 & 105 & $119,147,161,190,232,245$ \\
\hline 25.28 & 4.75 & 1-Nonadecene & 266 & 43 & $55,83,97,111,125,139,168$ \\
\hline 26.24 & 7.67 & 2-Methyl7-nonadecene & 280 & 43 & $57,69,83,97,111,125,252$ \\
\hline 26.62 & 14.42 & n-Docosane & 310 & 43 & $57,71,85,99,113,127,239$ \\
\hline 26.77 & 6.88 & 1-Docosanol & 326 & 43 & $55,69,83,97,111,125$ \\
\hline 27.05 & 3.47 & Ergosta-5,22-dien-3 $\beta$-ol & 398 & 398 & $\begin{array}{c}199,213,255,271,300,337,355, \\
365\end{array}$ \\
\hline 27.60 & 2.89 & $5 \alpha$-Ergost-7-en- $3 \beta$-ol & 400 & 43 & $213,255,273,327,357$ \\
\hline 28.51 & 4.25 & Stigmast-5-en- $3 \beta$-ol & 414 & 414 & $\begin{array}{c}199,213,231,241,255,273,303 \\
329,339,367,381,396\end{array}$ \\
\hline 39.48 & 6.51 & 17-Pentatriacontene & 490 & 43 & $57,83,97,111,125,139,462$ \\
\hline \multicolumn{6}{|c|}{$\begin{array}{l}\text { Saturated Hydrocarbons: } 40.73 \% \\
\text { Unsaturated Hydrocarbons: } 18.93 \% \\
\text { Fatty alcohols: } 10.08 \% \\
\text { Sterols: } 10.61 \%\end{array}$} \\
\hline Total ide & ied con & ids: $80.35 \%$ & & & \\
\hline
\end{tabular}

Rt: Retention time

Egypt. J. Chem. 62, No. 2 (2019) 
compounds have been elucidated by comparing their pectroscopical results with those published data.

Study of structure of the isolated compounds

Compound 1 ( $\beta$ sitosterol) (Fig. 1a): isolated from petroleum ether: chloroform $(75: 25)$ as white crystal, $\mathrm{R}_{\mathrm{f}} 0.69$, melting point $133-134{ }^{\circ} \mathrm{C}$ which in agreement with that reported in literature[63], UVmax: 203, EI-MS m/z (relative intensity): 414 $(54 \%)$ for the molecular formula $\mathrm{C}_{29} \mathrm{H}_{50} \mathrm{O}$, and base peak (100\%) at $m / z 43$, in addition to other significant fragments at $369(63 \%)$ corresponds to $(\mathrm{M}-45)$ due to loss of $\mathrm{HO}^{+}=\mathrm{CH}-\mathrm{CH}_{3}$, also, 271 $(22 \%)$ as a result of the formation of carbonation by $\beta$ bond cleavage of side chain leading to the loss of $\mathrm{C}_{10} \mathrm{H}_{23}$ that corresponds to the $\mathrm{M}-143$, beside to $396(28 \%)$ due to the loss of a water molecule and $133(18 \%), 105(23 \%), 107$ (26\%), 95 (31\%), 81 (34\%), 69 (32\%), 55 (41\%).
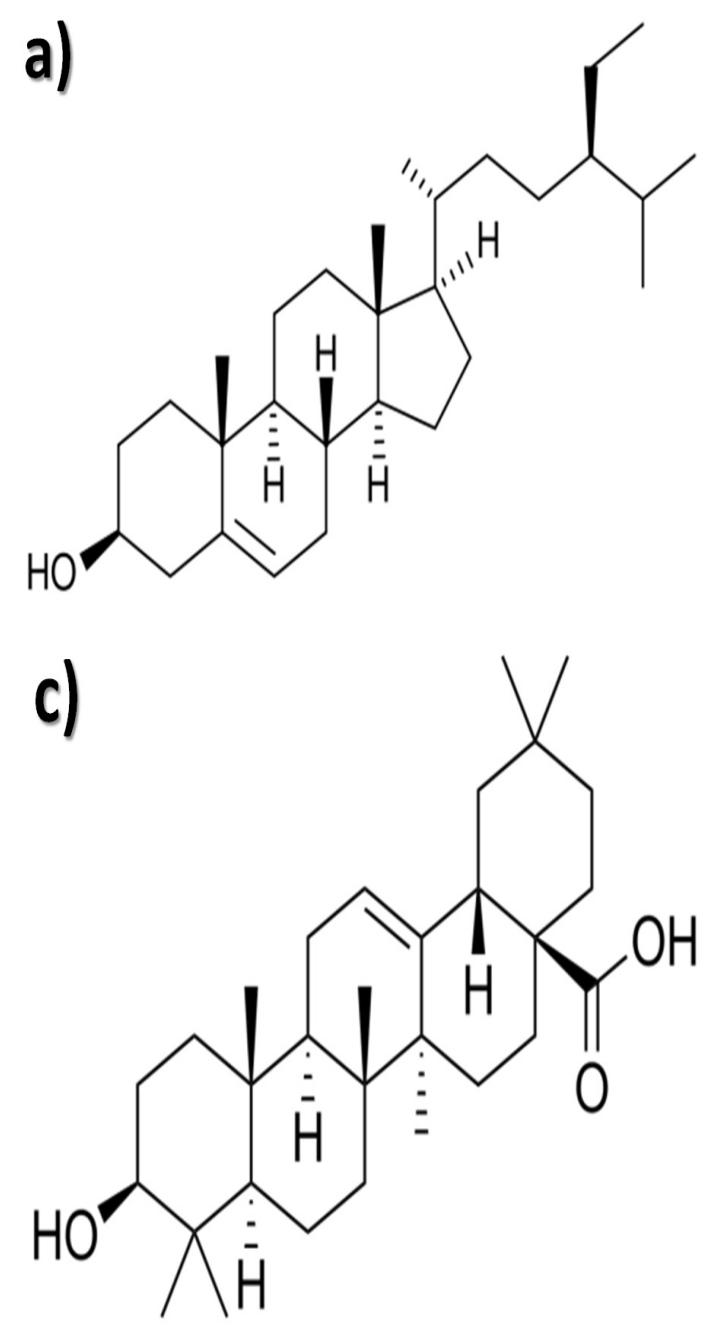

The IR absorption spectrum $\left(\mathrm{KBr}, \mathrm{cm}^{-1}\right)$ showed absorption peaks at $3379(\mathrm{O}-\mathrm{H}$ stretch), 2943 and 2865 (C-H stretch), 1685 (Olefinic $\mathrm{C}=\mathrm{C}$ ), other absorption peaks were 1455 (Aromatic $\mathrm{C}=\mathrm{C}$ Stretch), 1388 (Aromatic C-H Bending), 1036 (C$\mathrm{OH}$ Stretch) and 885 (O-H Bending).

${ }^{1} \mathbf{H}-\mathbf{N M R}\left(\delta\right.$ values, $\left.\mathrm{CDCl}_{3}\right): 5.29(1 \mathrm{H}, \mathrm{H}-6)$ indicated the presence of an olefinic proton at C-6 owing to the double bond between C-5 and C-6, the presence of two singles at $0.66(3 \mathrm{H}, \mathrm{s}, \mathrm{Me}-18)$ and $1.12(3 \mathrm{H}, \mathrm{s}, \mathrm{Me}-19)$ refer to the angular methyl groups $\mathrm{C}-18$ and $\mathrm{C}-19$. Also the appearance of three doublets at $\delta 1.04(3 \mathrm{H}, \mathrm{d}, \mathrm{Me}-21), 0.83(3 \mathrm{H}, \mathrm{d}$, $J=6.8 \mathrm{~Hz}, \mathrm{Me}-26), 0.80$ (3H,d, $J=6.4 \mathrm{~Hz}, \mathrm{Me}-27)$, and one triplet at $0.86(3 \mathrm{H}, \mathrm{t}, J=6.6 \mathrm{~Hz}, \mathrm{Me}-29)$ confirm the presence of C-21, C-26, C-27, and C-29 methyl groups, respectively.

${ }^{13}$ C-NMR: $\delta 11.89$ (C-18), 11.98(C-29),

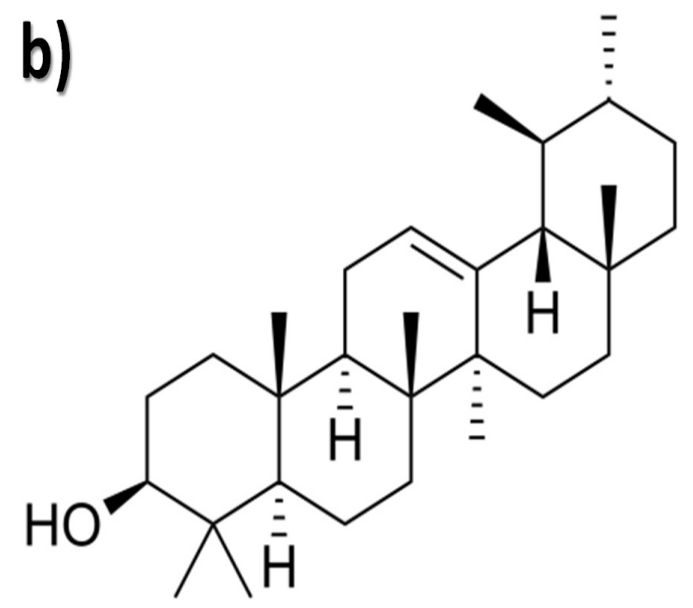<smiles>C=C[C@H](CC[C@H](C)C(C)C)[C@H]1CCC2C3CC=C4C[C@@H](OC5CCCCC5)CC[C@]4(C)C3CC[C@]21C</smiles>

Fig. 1. Structure of the isolated compounds: a) $\beta$ sitosterol, b) $\alpha$-amyrin, c) Oleanolic acid and d) 3-O- $\beta$-Dglucopyranosyl- $\beta$-sitosterol . 
18.69(C-21), 18.82(C-27), 19.34(C-19), 19.56(C26), 21.42(C-11), 23.18(C-28), 24.35(C-15), 26.31(C-23), 28.36(C-16), 29.27(C-25), 31.64(C2), 31.94(C-7), $32.17 \quad(\mathrm{C}-8), \quad 32.48(\mathrm{C}-22)$, 34.15(C-20), 36.35(C-10), 36.75(C-1), 37.45(C4), 39.79(C-12), 42.36(C-13), 45.64(C-24), 50.13(C-9), 56.21(C-17), 56.72(C-14), 77.31(C3), 121.46 (C-6), 140.72(C-5).

Compound 2 ( $\alpha$-amyrin) (Fig. 1b): isolated from petroleum ether : chloroform (50:50) as white needle crystals, $R_{f} 0.66$, melting point $185-186{ }^{\circ} \mathrm{C}$ as stated by Siratet al. [64]. UV data displayed characteristic absorption bands at 275 , 260, $243 \mathrm{~nm}$, EI-MS m/z (relative intensity) shows molecular ion at $\mathrm{m} / \mathrm{z} 426(30 \%)$ which is consistent with the molecular formula $\mathrm{C}_{30} \mathrm{H}_{50} \mathrm{O}$ [65], base peak $(100 \%)$ at $\mathrm{m} / \mathrm{z} 218$, in addition to other characteristic fragments at $43(57 \%), 55$ (43\%), 57 (31\%), 71 (23\%), 95 (63\%), 127 (24\%), 175 (13\%), 189 (11\%), 203 (28\%), 257 (9\%), 293 (13\%), $409(7 \%), 411(18 \%)$.

The IR spectrum $\left(\mathrm{KBr}, \mathrm{cm}^{-1}\right)$ showed absorption peaks at 3438 (O-H Stretch), 3021, 2980, 2934, 2850, 2724 (C-H in conjugation), 1652 (ethylenic double bond), 1458 (aromatic $\mathrm{C}=\mathrm{C}$ Stretch), 1372 (aromatic C-H Bending), 1124, 1021 (C-OH Stretch), 974, 886 (O-H bending).

${ }^{1} \mathbf{H}$ NMR $\left(\delta\right.$ values, $\left.\mathrm{CDCl}_{3}\right): 0.84(\mathrm{~s}, 3 \mathrm{H},-$ $\left.\mathrm{CH}_{3}\right), 0.89\left(\mathrm{~d}, 3 \mathrm{H}, J=7 \mathrm{~Hz},-\mathrm{CH}_{3}\right), 1.06(\mathrm{~d}, 3 \mathrm{H}$, $J=7.0 \mathrm{~Hz},-\mathrm{CH}_{3}$ ), indicating the triterpenoidal nature, $1.27-1.30(\mathrm{~d}, 6 \mathrm{H}, J=7 \mathrm{~Hz}$, two secondary $\left.-\mathrm{CH}_{3}\right)$ indicating the isopropenyl skeleton, 1.35 (s, 3H, $-\mathrm{CH}_{3}$ at $\left.\mathrm{H}-29\right) 1.49$ (m, 2H, H-16), 1.53 (m, 2H, H-21), 1.59 (d, 1H, J=11.5 Hz, H-18), $1.67\left(\mathrm{~s}, 7 \mathrm{H},-\mathrm{CH}_{3} \times 2\right.$ and $\left.\mathrm{H}-5\right), 1.78(\mathrm{~m}, 1 \mathrm{H}$, $\mathrm{H}-19), 1.80$ (m, 2H, H-22), 1.89 (m, 2H, H-15), $2.02(\mathrm{~d}, 2 \mathrm{H}, J=11.5 \mathrm{~Hz}, \mathrm{H}-1), 2.06$ (s, 1H, H-9), 2.20-2.27 (d, 2H, $J=11.5 \mathrm{~Hz}, \mathrm{H}-1$ and H-16), 3.49 (s, 2H, H-7), 3.59 (m, 2H, H-2), 5.09 (s, 2H, $\mathrm{H}-11), 5.16$ (s, 1H, H-12).

${ }^{13}$ CNMR: $\delta 15.5$ (C-24, C-25), 16.9 (C-26), 17.6 (C-29), 18.5 (C-6), 21.6 (C-30), 23.2 (C-27), 23.5 (C-11), 26.5 (C-16), 27.1 (C-15), 28.2 (C-23, C-28), 28.7 (C-2), 31.3 (C-21), 32.4 (C-7), 33.9 (C-17), 36.7 (C-10), 38.8 (C-1, C-4), 39.6 (C-19, C-20), 40.6 (C-8), 41.4 (C-22), 42.1 (C-14), 47.8 (C-9), 55.2 (C-5), 59.2 (C-18), 79.7 (C-3), 124.6 (C-12), 139.4 (C-13).

Compound 3 (Oleanolic acid) (Fig. 1c): isolated from petroleum ether : chloroform (50:50) as white amorphous solid, $\mathrm{R}_{\mathrm{f}} 0.62$, melting point at $173{ }^{\circ} \mathrm{C}$ as stated in Galgon et al. [66].UV max at $205 \mathrm{~nm}, \mathbf{E I}-\mathbf{M S ~ m} / \mathrm{z}$ (relative intensity): 457 (43\%) for the molecular formula $\mathrm{C}_{30} \mathrm{H}_{48} \mathrm{O}_{3}$, and base peak (100\%) at $\mathrm{m} / \mathrm{z} 439$ characteristic for pentacyclictriterpene skeleton with a 12-13 double bond, 411 (59\%), 247 (61\%), 203 (23\%), $191(14 \%), 177(24 \%)$.

The IR spectrum $\left(\mathrm{KBr}, \mathrm{cm}^{-1}\right)$ showed absorption peaks at 3465 (O-H Stretch), 2957, 2855 (C-H Stretch), 1695(olefinic C=C), 1458 (Aromatic $\mathrm{C}=\mathrm{C}$ Stretch), 1396, 1367, 1330 (Aromatic C-H Bending), 1184, 1161, 1030 (COH Stretch), 990, 865 (O-H bending).

${ }^{1}$ H-NMR ( $\delta$ values, $\left.\mathrm{CDCl}_{3}\right): 0.77,0.88,0.89$, $0.92,0.96,1.07$ and $1.32\left(7 \mathrm{~s}, 21 \mathrm{H}\right.$, all $\left.-\mathrm{CH}_{3}\right)$, $1.38(\mathrm{~m}, 2 \mathrm{H}, \mathrm{H}-21), 1.40$ (m, 2H, H-16), 1.54 (m, 5H, H-18, H-19 and H-15), 2.11 (m, 3H, H-1 and $\mathrm{H}-9), 3.20(\mathrm{t}, 1 \mathrm{H}, J=7 \mathrm{~Hz}, \mathrm{H}-2), 3.41$ (s, 2H, H-7), 4.55 (s, 2H, H-11), 4.62 (s, 1H, H-12). ${ }^{1} \mathrm{H}-\mathrm{NMR}$ data showed the presence of an olefinic proton resonating at $\delta 4.62(1 \mathrm{H})$ (typical of oleane skeleton which was assigned to $\mathrm{H}-12$ ).

${ }^{13}$ CNMR: $\delta 15.11$ (C-25), 15.58 (C-24), 16.67 (C-26), 18.11 (C-6), 22.78 (C-11), 23.13 (C-30), 23.48 (C-16), 25.68 (C-27), 26.94 (C-2), 27.49 (C15), 28.01 (C-23), 30.47 (C-20), 32.24 (C-22), 32.54 (C-7), 32.97 (C-29), 33.69 (C-21), 37.01 (C10), 37.89 (C-1), 38.52 (C-4), 39.24 (C-8), 41.02 (C-18), 42.13 (C-14), 45.76 (C-17), 46.23 (C-19), 47.85 (C-9), 54.79 (C-5), 79.34 (C-3), 121.89 (C12), 144.51 (C-13), 182.03 (C-28). The presence of oleane skeleton was confirmed in the ${ }^{13} \mathrm{C}-\mathrm{NMR}$ data with the signals in the region $\delta 15.11 \mathrm{ppm}$, at $\delta 121.89$ and $\delta 144.51$ attributed respectively to seven methyl groups, to $\mathrm{C}-12, \mathrm{C}-13$ and $12-$ oleane skeleton.

Compound 4 (3-O- $\beta$-D-glucopyranosyl- $\beta$ sitosterol (daucosterol)) (Fig. 1d): isolated from petroleum ether : chloroform $(25: 75)$ as white crystals, $\mathrm{R}_{\mathrm{f}} 0.58$, melting point $281-282^{\circ} \mathrm{C}$ which in agreement with that stated byFaiziet al. [67].UV max: 205 and $197 \mathrm{~nm}$. EI-MS m/z (relative intensity): $576(36 \%)$ for the molecular formula $\mathrm{C}_{35} \mathrm{H}_{60} \mathrm{O}_{6}$, and base peak $(100 \%)$ at $\mathrm{m} / \mathrm{z}$ 57 , the other significant peaks were $414(56 \%)$ corresponding to $\left(\mathrm{M}^{+}\right.$-glycosidic unit), 396 $(47 \%)$ indicated the loss of a water molecule from $\beta$-sitosterol nucleus, beside 381 (34\%), 329 (26\%), 303(18\%), and 275 (24\%).

The IR absorption spectrum $\left(\mathrm{KBr}, \mathrm{cm}^{-1}\right)$ showed absorption peaks at $3385(\mathrm{O}-\mathrm{H}$ stretch), 2865 (C-H stretch), 1655 (olefinic $\mathrm{C}=\mathrm{C}$ ), other absorption peaks are 1452 (Aromatic $\mathrm{C}=\mathrm{C}$ 
Stretch), 1385 (Aromatic C-H Bending), 1055 (C$\mathrm{OH}$ Stretch) and 892 (O-H bending).

${ }^{1}$ H-NMR $\left(\delta\right.$ values, $\left.\mathrm{CDCl}_{3}\right): 5.34(1 \mathrm{H}, \mathrm{br}, \mathrm{H}-6)$ for the anolefinic proton at C-6, $4.18(1 \mathrm{H}, \mathrm{d}, J=7.8$ $\left.\mathrm{Hz}, \mathrm{H}-1^{\prime}\right), 3.54$ (1H, m, H-3), and $3.41(1 \mathrm{H}, \mathrm{d}$, H-2').

${ }^{13}$ CNMR: $\delta$ ppm11.4 (C-18), 11.9 (C-29), 18.2 (C-21), 18.7 (C-27), 19.1 (C-19), 19.4 (C26), 20.6 (C-11), 21.9 (C-28), 25.0 (C-15), 26.2 (C-23), 28.5 (C-16), 28.9 (C-2), 29.6 (C-25), 30.8 (C-7/8), 33.6 (C-22), 35.4 (C-20), 36.0 (C-10), 36.7 (C-1), 37.8 (C-4), 39.6 (C-12), 42.1 (C-13), 44.9 (C-24), 49.3 (C-9), 55.2 (C-17), 56.4 (C-14), 61.3 (C-6'), 71.2 (C-4'), 73.7 (C-2'), 76.9 (C-3), 77.4 (C-3'/5'), 100.6 (C-1'), 121.4 (C-6), 140.3 (C-5). The acid hydrolysis of the compound led to the presence of glucose in aqueous layer and $\beta$-sitosterol in the organic layer and by comparing with authentic reference samples in addition to the literature [68], the compound was identified as $\beta$-sitosterol-3-O-glucopyranoside.

Among the all noble metal nanoparticles, the Ag-NPs gained boundless interests due to their characteristic properties in addition to their significant antibacterial, antiviral, antifungal and anti-inflammatory effects. Moreover, silver exhibits vital functions as an antiseptic and displays a broad biocidal effect against various microorganisms through disruption of their unicellular membrane thus disturbing their enzymatic activities [69, 70]. Many reports have been published concerning synthesis of Ag-NPs using plant extracts revealed that the nanoparticulated extracts were economic, energy efficient and cost effective, in addition this technique provide healthier work places, communities, protecting human health and environment, leading to less waste and more safe products [71-73]. For this reason, during the current study, they can be incorporated into C. tiglium seeds extract to raise its antioxidant efficiency to be used for therapeutic purposes.

Assessment of the structure and morphology of fabricated nanomaterials

The XRD as well as TEM consider the most significant technique to examine structural properties of the fabricated nanomaterials. The Ag-NPs were prepared and studied using the XRD diffraction pattern. As revealed in Fig. 2a, it was noticed that XRD result of the prepared AgNPs displayed the characteristic peaks of metallic $\mathrm{Ag}^{\circ}$ found at $37.8^{\circ}, 44.5^{\circ}$ and $67.6^{\circ}$ matching with the crystallographic planes ( $\left.\begin{array}{lll}1 & 1 & 1\end{array}\right),\left(\begin{array}{lll}0 & 0 & 2\end{array}\right)$ and $\left(\begin{array}{lll}0 & 2\end{array}\right.$ 2 ) of Ag-NPs, respectively and generates a typical of crystalline metallic Ag phase.

Also, XRD displayed separate diffraction peaks around $37.8^{\circ}$, which were indexed by the (002) of the cubic face-centered silver. These sharp Bragg peaks may as a result of capping agent using for stabilizing the prepared Ag-NPs. Strong Bragg reflections recommend that strong X-ray scattering centers in the crystalline phase and might be because of capping agents. An increase in the incubation time with $\mathrm{Ag}-\mathrm{NO}_{3}$ solution along with plant extract the synthesis of Ag-NPs increased. Presence of the plant extract reduced formation of $\mathrm{AgNO}_{3}$ into $\mathrm{Ag}$ ions. Moreover, the secondary metabolites present in the extract act as a reducing and a capping agent for Ag-NPs synthesis [74-78].

In order to assess the shape, size and morphology of nanoparticles, TEM was used. It was revealed that the Ag-NPs were well dispersed and were predominantly spherical in shape, while some of the NPs were irregular in shape. Based on the obtained morphological data using TEM (Fig. 2b), it was demonstrated that the Ag-NPs was formed as a result of the chemical reduction which was carried out in presence of $\mathrm{AgNO}_{3}$ solution. Presence of $\mathrm{Ag}$ nanoparticles maintained the homogeneity and uniformity of the distribution of Ag-NPs in the particles size range $(5-10 \mathrm{~nm})$ as revealed from TEM image. It was revealed that the Ag-NPs were well dispersed and were predominantly spherical in shape, while some of the NPs were irregular in shape. This was in agreement with findings of the experiment carried out by Ahmed and Ikram [79]. Furthermore, evidence for the formation of Ag-NPs prepared within the chemical reduction method was demonstrated using UV-visible spectroscopy. This technique is a precise suitable and reliable method for the main characterization of manufactured nanoparticles which is correspondingly used to display the Fabrication as well as stability of AgNPs.

The Ag-NPs have exceptional optical properties that generate strongly interrelate with exact wavelengths of light. Also, UV-Vis spectroscopy is easy, fast, simple and discerning for various types of NPs, requests simply a short period time for measurement. As illustrated in Fig. 2c, the prepared Ag-NPs showed a sharp peak at $450 \mathrm{~nm}$ that reveals the formation of Ag-NPs. Consequently, DLS is mostly used to determine 
a)

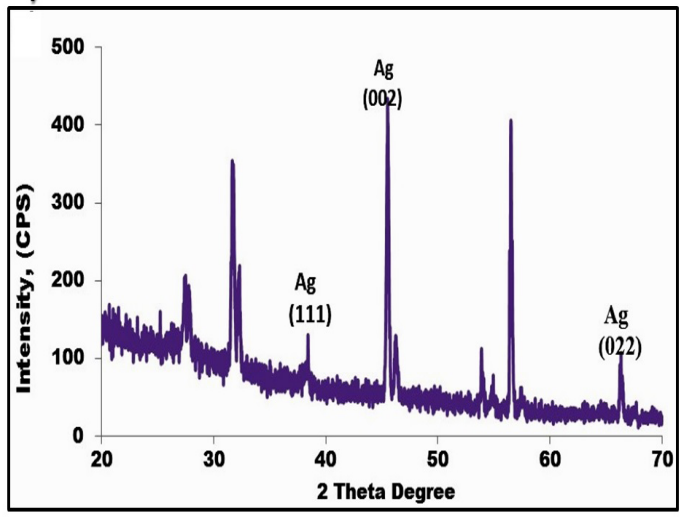

c)

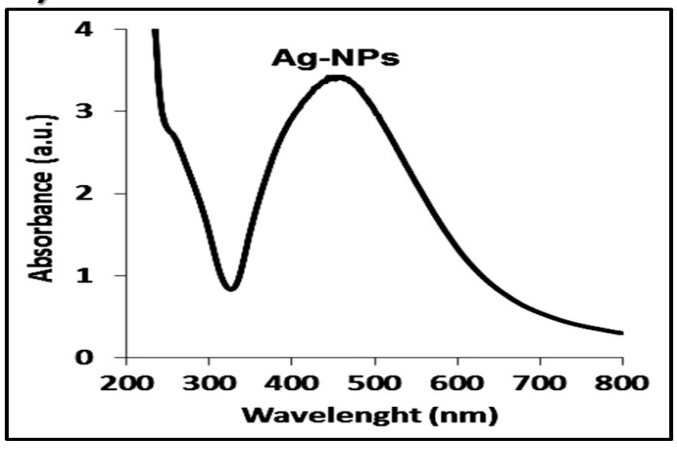

b)

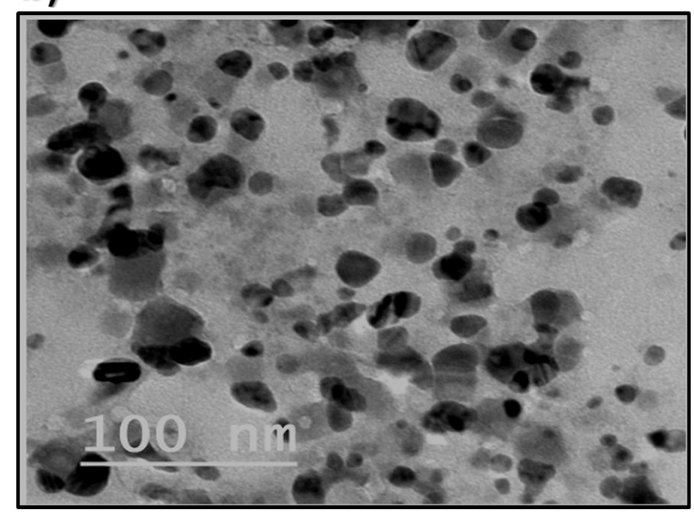

d)

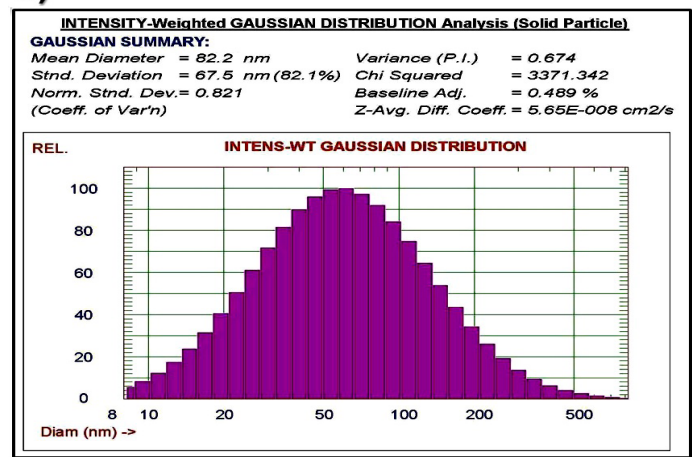

Fig. 2. a) XRD pattern of the prepared Ag-NPs, b) TEM image of Ag-NPs, c) UV-spectroscopy of the prepared Ag-NPs and d) DLS of the Ag-NPs.

particle size as well as size distributions in aqueous solutions. The size attained from DLS is frequently larger than that particle size obtained from TEM, which might be because of the effect of Brownian motion. DLS is a nondestructive technique used to acquire the average diameter of the prepared dispersed nanoparticles in aqueous solutions. As presented in Fig. 2d, it was found that the particle size distribution of the fabricated Ag-NPs has main diameter around $82 \mathrm{~nm}$.

The plants were effectively involved in synthesis and controlled formation of AgNPs. The nanoparticles size differs from TEM to DLS and this may be the reason of particles agglomeration. Furthermore, the nanoparticles exhibited good stability and this might be due to presence of secondary metabolites as a capping or reducing agent [80].

Total antioxidant capacity and free radical scavenging activity in different $C$. tiglium seeds extracts before and after incorporating $\mathrm{Ag}-\mathrm{NPS}$.

Polyphenols are the most common biologically active molecules. They are structurally characterized by presence of one or more phenol units. They are considered as one of the most important classes of secondary plant metabolites that play an important role in prevention of chronic diseases owing to their antioxidants potentials [81 $\&$ 82]. As illustrated in Table 9, it was found that the aqueous $C$. tiglium seeds extract contains the highest concentration of polyphenolic compounds (699.21 $\pm 6.93 \mathrm{mg}$ gallic acid/100 gm) as compared to the other extracts. This was in agreement with the study suggested by Salatino et al. [52] who reported that these phenolic compounds were represented mainly by flavonoids, lignoids and proanthocyanidins predominate. It was shown that the nanoparticulated extracts exhibited elevated concentrations on total polyphenolic compounds in ethanolic, petroleum ether and aqueous $C$. tiglium seeds extracts $(873.54 \pm 9.31$, $485.91 \pm 5.18$ and $962.05 \pm 10.25 \mathrm{mg}$ gallic acid/100 gm, respectively) than the crude extracts $(617.87 \pm 3.85,388.24 \pm 6.47$ and $699.21 \pm 6.93$ $\mathrm{mg}$ gallic acid/100 gm, respectively). This was in accordance with Abdelhady and Badr [83] who reported that incorporation of Ag-NPs increased concentration of the polyphenolic compounds with respect to the native extract (without AgNPs). 
In addition, it was noticed that the aqueous $C$. tiglium seeds extract proved promising antioxidant capacity, total reducing power and free radical scavenging activity by $0.856 \pm 0.019 \mathrm{mg}$ gallic acid / gm, $8.81 \pm 1.10$ and $73 \%$, respectively. The antioxidant properties of the seeds extract might be attributed to presence of the main components of the antioxidant fractions ( $\alpha$-bisabolol, $\alpha$ - eudesmol and guaiol) [84]. In addition, the aromatic acids (vanillic and 4-hydroxy-benzoic acid along with N-methyltyrosine) have shown remarkable antioxidant activity [85]. Furthermore, it was noticed that incorporation of Ag-NPs enhanced the antioxidant properties through increasing the total antioxidant capacity, total reducing power and free radical scavenging activity in comparison with the native extracts. This was in accordance with Abdelhady and Badr [83] who suggested that nanoparticulated extracts increased levels of the active phytoconstituents which exhibit more antioxidant potentials and possesses significant free radical scavenging activity than the crude extracts.

The in vitro anticancer activity showed that the seeds powder and ethanol extract exhibited equal anticancer activity against human colon cancer cells with $\mathrm{IC}_{50} 36.3 \mu \mathrm{g} / \mathrm{mL}$ ). This was in accordance with Mohd Ali et al. [86] who reported that the ethanolic Croton extracts exhibited high antioxidant activity by means of DPPH radical scavenging activity, reducing power and total antioxidant capacity. Furthermore, this might be due to the highest total phenolic and total flavonoid content, thus suggesting the potential use of $C$. tiglium seeds extract as a natural source of antioxidant. Petroleum ether extract showed no anticancer activity. This might refer to presence of the essential oils that have limited cytotoxicity against colon carcinoma [87]. While the aqueous extract showed anticancer activity with $\mathrm{IC}_{50} 33.9$ $\mu \mathrm{g} / \mathrm{mL}$. This might be attributed to presence of wide range of the phytochemical constituents that can inhibit the process of carcinogenesis effectively and prevent the development of invasive cancer $[88,89]$. As suggested byAbdelhady and Badr [83], incorporation of Ag-NPs into the different extracts increased the cytotoxicity against growth of human colon cancer cells compared to the crude ones. This was manifested by their reduced $\mathrm{IC}_{50}$ for different used cell lines. This attributed to enhancement of total polyphenolic compounds, the total antioxidant capacity, iron reducing

TABLE 9. Total antioxidant capacity and free radical scavenging activity in different $C$. tiglium seeds extracts before and after incorporating Ag-NPs.

\begin{tabular}{|c|c|c|c|c|c|c|}
\hline Solvent & 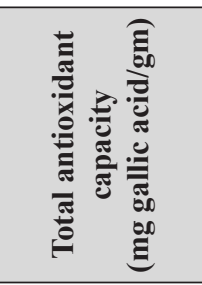 & 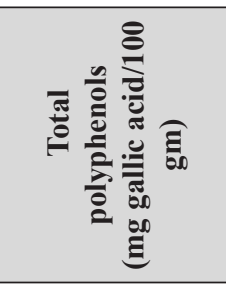 & 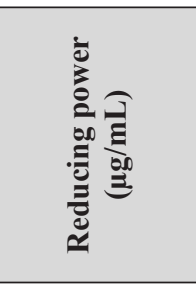 & 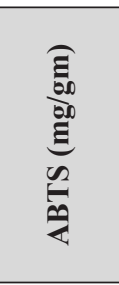 & อิ & 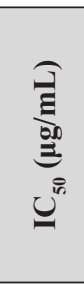 \\
\hline Seeds & $0.570 \pm 0.014$ & $487.18 \pm 9.40$ & $7.25 \pm 0.91$ & 22.521 & $62 \%$ & 36.3 \\
\hline \multirow{3}{*}{ Ethanol } & $0.444 \pm 0.002$ & $617.87 \pm 3.85$ & $3.30 \pm 0.42$ & 21.205 & $53 \%$ & 36.3 \\
\hline & & & & & & \\
\hline & $0.60 \pm 0.04$ & $873.54 \pm 9.31$ & $7.06 \pm 0.88$ & 29.45 & $71 \%$ & 18.75 \\
\hline \multirow{3}{*}{ P. ether } & $0.217 \pm 0.009$ & $388.24 \pm 6.47$ & $0.37 \pm 0.08$ & 0.838 & $22.2 \%$ & 50 \\
\hline & & & & & & \\
\hline & $0.36 \pm 0.02$ & $485.91 \pm 5.18$ & $4.31 \pm 0.54$ & 1.25 & $35.7 \%$ & 23 \\
\hline \multirow{3}{*}{ Aqueous } & $0.856 \pm 0.019 *$ & $699.21 \pm 6.93 *$ & $8.81 \pm 1.10 *$ & $41.525 *$ & $73 \% *$ & $33.9 *$ \\
\hline & & & & & & \\
\hline & $1.08 \pm 0.06^{*}$ & $962.05 \pm 10.25^{*}$ & $14.21 \pm 1.78^{*}$ & $62.74 \%$ & $87 \% *$ & 3.13* \\
\hline
\end{tabular}

*: The most effective extract as compared to the others, Value expressed as mean $\pm \mathrm{SE}$ of four replicates 
power and free radicals scavenging activity and hence increasing the anticancer activity through lowering growth of the cancer cells.

Incorporation of Ag-NPs into the extract caused no toxicity in the experimental animals when administrated orally by stomach tube. This was in accordance with the concept reported by Mohanpuria et al. [90] who suggested that green route synthesis of Ag-NPs found with less toxicity. This was supported by our findings that emphasized that the $\mathrm{LD}_{50}$ of the ethanolic seeds extract-Ag nanocomposite was about7.95 ml/ Kgandthe therapeutic dose was about $0.8 \mathrm{ml} /$ $\mathrm{Kg}$. In the petroleum ether seeds extract-Ag nanocomposite, the $\mathrm{LD}_{50}$ was about $5.2 \mathrm{ml} / \mathrm{Kg}$ and hence the therapeutic dose was $0.52 \mathrm{ml} / \mathrm{Kg}$. Moreover, the aqueous $C$. tiglium seeds extract$\mathrm{Ag}$ nanocomposite was found with $\mathrm{LD}_{50}$ about 65 $\mathrm{ml} / \mathrm{Kg}$ and hence the therapeutic dose was about $6.5 \mathrm{ml} / \mathrm{Kg}$.

\section{Conclusions}

In this study, it was concluded that $C$. tiglium seeds contain various active phytoconstituents such as carbohydrates (glycosides), flavonoids, sterols (triterpenes), alkaloids (nitrogenous compounds) and proteins. Incorporation of Ag-NPs into the different extracts (ethanolic, petroleum ether and aqueous seeds extracts) enhanced the antioxidant properties through increasing the total antioxidant capacity, total reducing power and free radical scavenging activity in comparison with the crude extracts. Therefore, it was shown that the nanoparticulated extracts exhibited elevated cytotoxicity against growth of human colon cancer cells compared to the crude ones. No toxicity occurred as a result of incorporation of Ag-NPs into the extract when administrated orally by the experimental animals.

\section{Conflict of Interest}

The authors declare no potential conflicts of interest with respect to the research, authorship and/or publication of this article.

\section{References}

1. Hecker, E. Cocarcinogenic principles from the seed oil of Croton tiglium and from other Euphorbiaceae. Cancer Res., 28, 2338-2349 (1968).

2. Nath, R.; Roy, S.; De, B. and Choudhury, M.D. Anticancer and antioxidant activity of croton: A review. International Journal of Pharmacy and Pharmaceutical Sciences, 5 (Suppl 2), 63-70 (2013).

Egypt. J. Chem. 62, No. 2 (2019)
3. Wang, X.; Lan, M.; Wu, H.-P.; Shi, Y.-Q.; Lu, J.; Ding, J.; Wu, K.-C.; Jin, J.-P and Fan, D.M. Direct effect of croton oil on intestinal epithelial cells and colonic smooth muscle cells. World $J$. Gastroenterol, 8, 103-107 (2002).

4. Morimura, K. The role of special group article in ancient Chinese medical prescription. Hist. Sci. (Tokyo), 13, 1-12 (2003).

5. Tsai, J.C.; Tsai, S. and Chang, W.C. Effect of ethanol extracts of three Chinese medicinal plants with laxative properties on ion transport of the rat intestinal epithelia. Biol. Pharm. Bull., 27, 162-165 (2004).

6. Jasicka-Misiak, I.; Wieczorek, P.P. and Kafarski, P. Crotonic acid as a bioactive factor in carrot seeds (Daucus carota L.). Phytochemistry, 66, 14851491 (2005).

7. Saputera, Mangunwidjaja, D.; Raharja, S.; Kardono, L.B.S. and Iswantini, D. Characteristics, Efficacy and Safety Testing of Standardized Extract of Croton tiglium Seed from Indonesia as Laxative Material. Pakistan Journal of Biological Sciences, 11(4), 618-622 (2008).

8. Hu, J.; Gao, W.Y.; Gao, Y.; Ling, N.S.; Huang, L.Q. and Liu, C.X. M3 muscarinic receptorand $\mathrm{Ca}^{2+}$ influx-mediated muscle contractions induced by croton oil in isolated rabbit jejunum. $J$. Ethnopharmacol., 2129, 377-380 (2010).

9. Jamil, A.; Shahid, M.; Masud-Ul-Haq Khan, M. and Ashraf, M. Screening of some medicinal plants for isolation of antifungal proteins and peptides. Pakistan Journal of Botany, 39(1), 211-221 (2007).

10. Lin, H.C.; Kuo, Y.-L.; Lee, W.-J.; Yap, H.-Y. and Wang, S.-H. Antidermatophytic activity of ethanolic extract from Croton tiglium. Bio. Med. Research International, Volume 2016, Article ID 3237586, 6 pages (2016).

11. Sengul, M.; Yildiz, H.; Gungor, N.; Cetin, B.; Eser, Z. and Ercisli, S. Total phenolics content, antioxidant and antimicrobial activities of some medicinal plants. Pak J Pharm Sci, 22(1), 102-106 (2009).

12. Rickard, K.L.; Gibson, P.R.; Young, G.P. and Phillips, W.A. Activation of protein kinase C augments butyrate induced differentiation and turnover in human colonic epithelial cells in vitro. Carcinogenesis (Lond.), 20(6), 977-984 (1999).

13. Yumnamcha, T.; Nongthomba, U. and Devi, M.D. Phytochemical screening and evaluation of 
genotoxicity and acute toxicity of aqueous extract of Croton tiglium L. International Journal of Scientific and Research Publications, 4(1), 1-5 (2014).

14. El-Kamali, H.H.; Omran, A.M.E. and Abdalla, M.A. Biochemical and haematological assessment of Croton tiglium seeds mixed with animal diet in male albino rats. Annual Research \& Review in Biology, 8(4), 1-7 (2015).

15. Youssef, A.M. Morphological studies of polyaniline nanocomposite based mesostructured $\mathrm{TiO}_{2}$ nanowires as conductive packaging materials. RSC Advances, 4, 6811-6820 (2014).

16. Youssef, A. M.; El-Sayed, S. M.; El-Sayed, H.S.; Salama, H.H.; Assem, F.M. and Abd El-Salam, M.H. Novel bionanocomposite materials used for packaging skimmed milk acid coagulated cheese (Karish). International Journal of Biological Macromolecules, 115, 1002-1011 (2018).

17. Youssef, A.M.; Malhat, F.M.; Abdel Hakim, A. and Dekany, I. Synthesis and utilization of poly (methylmethacrylate) nanocomposites based on modified montmorillonite. Arabian Journal of Chemistry, 10, 631-642 (2017).

18. Youssef, A.M. and El-Sayed, S.M. Bionanocomposites materials for food packaging applications: Concepts and future outlook. Carbohydrate Polymers, 193, 19-27 (2018).

19. Youssef, A. M.; El-Nahrawy, A. M. and Abou Hammad, A.B Sol-gel synthesis and characterizations of hybrid chitosan-PEG/ calcium silicate nanocomposite modified with ZnO-NPs and (E102) for optical and antibacterial applications, International Journal of Biological Macromolecules. 97, 561-567(2017).

20. Nassar, M.A. and Youssef, A.M. Mechanical and antibacterial properties of recycled carton paper coated by PS/Ag nanocomposites for packaging. Carbohydrate Polymers, 89, 269-274 (2012).

21. Johnsona, A.S.; Obota, I.B. and Ukponga, U.S. Green synthesis of silver nanoparticles using Artemisia annua and Sida acuta leaves extract and their antimicrobial, antioxidant and corrosion inhibition potentials. J. Mater. Environ. Sci., 5(3), 899-906 (2014).

22. Abdel-Aziz, M.S.; Shaheen, M.S.; El-Nekeety, A.A. and Abdel-Wahhab, M.A. Antioxidant and antibacterial activity of silver nanoparticles biosynthesized using Chenopodium murale leaf extract. Journal of Saudi Chemical Society, 18, 356-363 (2014).

23. Kirk, R.S. and Sawyer, R. Pearson's Composition and Analysis of Foods, $9^{\text {th }}$ Ed., Longman group UK limited (1991).

24. Hasan, M.N.; Akhtaruzzaman, M. and Sultan, M.Z. Journal of Analytical Sciences, Methods and Instrumentation, 3(3A), 24-29 (2013).

25. Molisch, H. Monatsh. Chem., 7, through Stank, J.; Gerny, M.; Kocourek, J. and Pacak, J. (1963). The Monosaccharides, 872, Publishing House of Czechoslovak Academy of Science, Prague (1886).

26. Seikel, M.K. Chromatographic methods of separation, isolation and identification of flavonoid compounds, In: The Chemistry of Flavonoid Compounds. Geissman, T. A.; Macmillan Co., New York. p. 34 (1962).

27. Wagner, H.; Bladt, S. and Zgainsk, E.M. Plant Drug Analysis, Springer-Verlag, Berlin, Heidelberg, New York, Tokyo.p.291-304 (1984).

28. Smith, I. Chromatographic and Electrophoretic Techniques. Heinman, London (1960).

29. Mcgraw-Hill. Dictionary of Chemistry. $6^{\text {th }}$ Edition. Market House Books Ltd (2008).

30. Wallis, T.E. Text Book of Pharmacognosy, $5^{\text {th }}$ ed., J. and A. Churchill LTD, London. p. 449 (1967).

31. Dubois, M.; Gilles, K.A.; Hamilton, J.K.; Rebers, P.A. and Smith, F. Colorimetric method for determination of sugars and related substances. Anal. Chem., 28(3), 350-356 (1956).

32. Laidlow, M and Percival, V. J. Chem. Soc. 1, 531, through "The chemistry of gum and mucilage". Rembold Publishing Co. New York (1950).

33. Evans, W.V. "Pharmacognosy" $3^{\text {rd }}$ Ed., Balilliene Tindall; London (1962).

34. Matz, S.A. "'Food Texture". The Avi Publishing Company Inc.; West Port, Connecticut (1962).

35. Chrums, S.C. and Stephen, A.M. The determination of molecular weight distribution of maize starch dextrins by gel chromatography. J.S. Afr. Chem. Instit., 26, 46-50 (1973).

36. Pearson, D. The Chemical Analysis of Foods. $6^{\text {th }}$ ed., Churchill LTD., London, p. 9 (1970).

37. El-Gengaihi, S.; Karawya, M.; Selim, M.; Motawe, H. and Ibrahim, N. Chemical and biological investigation of polypeptides of Monordica and 
Luffa Dpp. Fam. Cucurbitaceae. J. Bull. NRC, 21, 269-276 (1996).

38. Widner, K. and Eggum, O.B. Protein analysis: A description of the method used at the department of animal physiology in Copenhagen. Acta Agricultura Scandinavi, 16, 15 (1966).

39. Swift, M.L. Analysis of molluscan sterols: colorimetric methods. Lipids, 19(8), 625 (1984).

40. Tsuda, K.; Sakai, K.; Tanabe, K. and Kishida, Y. Isolation of 22- dehydrocholestrol from Hypnea japonica. J. Am. Chem. Soc., 82: 1442-1443 (1960).

41. Finar, I.L. Organic Chemistry, $5^{\text {th }}$ ed., Longmans Green and Co. Ltd., London. p. 1- 212 (1967).

42. Adams, P. Identification of Essential Oils by Ion Trap Mass Spectroscopy, Academic Press, INC, New York (1989).

43. Singleton, V.L. and Rossi, J.A. Colorimetry of total phenolics with phosphomolybdicphosphotungstic acid reagents. Am. J. Enol. Vitic., 16 (3), 144-158 (1965).

44. Prieto, P.; Pineda, M. and Aguilar, M. Spectrophotometric quantitation of antioxidant capacity through the formation of a phosphomolybdenum complex: Specific application to the determination of vitamin E. Anal. Biochem., 269, 337-341 (1999).

45. Oyaizu, M. Studies on product of browning reaction prepared from glucose amine. Japanese Journal of Nutrition, 44, 307-315 (1986).

46. Brand-Williams, W.; Cuvelier, M.E. and Berset, C. Use of a free radical method to evaluate antioxidant activity. Lebenson Wiss Technol., 28, 25-30 (1995).

47. Arnao, M.B.; Cano, A. and Acosta, M. The hydrophilic and lipophilic contribution to total antioxidant activity. Food Chem., 73, 239-44 (2001).

48. Vichai, V. and Kirtikara, K. Sulforhodamine B colorimetric assay for cytotoxicity screening. Nature Protocols, 1(3), 1112-1116 (2006).

49. Paget, G.E. and Barnes, J.M. Toxicity tests. In: Laurance DR, Bacharach AL, editors. Evaluation of Drug Activities: Pharmacometrics, Vol 1. New York: Academic Press: p. 135-65 (1964).

50. Ganer, J.M.; Nikam, V.V.; Umapati, C.B. and Pramod, C.B. Pharmacognostic, phytochemical and physicochemical investigation of Croton tiglium seeds. International Journal of Pharmacy, 4(3), 140-145 (2014).

51. Pal, P. K.; Nandi, M.K. and Singh, N.K. Detoxification of Croton tiglium L. seeds by Ayurvedic process of Śdhana. Anc. Sci. Life, 33(3), 157-161 (2014).

52. Salatino, A.; Salatino, M.L.F. and Negri, G. Traditional uses, chemistry and pharmacology of Croton species (Euphorbiaceae). J. Braz. Chem. Soc., 18(1), 11-33 (2007).

53. Stray, F. The Natural Guide to Medicinal Herbs and Plants. London: Tiger Books International (1998).

54. Lopes, M.I.L.; Saffi, J.; Echeverrigaray, S; Henriques, J.A.P. and Salvador, M. Mutagenic and antioxidant activities of Croton lecheri sap in biological systems. Journal of Ethnopharmacology, 95, 437-445 (2004).

55. Liu, W.; Di Giorgio, C.; Lamidi, M.; Elias, R.; Ollivier, E. and De Meo, M.P. Genotoxic and clastogenic activity of saponins extracted from Nauclea bark as assessed by the micronucleus and the comet assays in Chinese Hamster Ovary cells. Journal of Ethnopharmacology, 137, 176-183 (2011).

56. Abbas, M.; Shahid, M.; Iqbal, M.; Anjum, F.; Sharif, S.; Ahmed, S. and Pirzada, T. Antitermitic activity and phytochemical analysis of fifteen medicinal plant seeds. Journal of Medicinal Plants Research, 7(22), 1608-1617 (2013).

57. Bello, M.O.; Abdul-Hammed, M.; Adekunle, A.S. and Fasogbon, O.T. Nutrient contents and fatty acids profiles of leaves and seeds of Croton zambesicus. Advance Journal of Food Science and Technology, 6(3), 398-402 (2014).

58. Okwu, D.E. and Emenike, I.N. Evaluation of the phytonutrients and vitamin contents of citrus fruits. Int. J. Mol. Med. Adv. Sci., 2(1), 1-6 (2006).

59. Okwu, D.E. and Nnamdi, F.U. Evaluation of the chemical composition of Dacryodes Edulis and Raphia Hookeri Mann and Wendl exudates used in herbal medicine in South Eastern Nigeria. Afr. $J$. Trad. Comp. Alt. Med., 5(2), 194-200 (2008).

60. Okwu, D.E. and Omodamiro, D.O. Effect of hexane extract and phytochemical content of Xylopia aethiopica and Ocimum gratissimum on uterus of guinea pig. Bio-Res., 3(2), 40-44 (2005).

61. Lan, M.; Wan, P.; Wang, Z.Y. and Huang, X.L. GC-

Egypt. J. Chem. 62, No. 2 (2019) 
MS analysis of chemical components in seeds oil from Croton tiglium. Zhong Yao Cai., 35(7), 11051108 (2012).

62. Stahl, E. Thin Layer Chromatography $A$ Laboratory Hand Book, $2^{\text {nd }}$ ed., Springer Verlag, Berlin, Heidelberg, New York. 855, 857 and 904 (1969).

63. Habib, M. R.; Nikkon, F.; Rahman, M.; Haque, M.E. and Karim, M.R. Isolation of stigmasterol and beta-sitosterol from methanolic extract of root bark of Calotropis gigantea (Linn). Pak. J. Biol. Sci., 10(22), 4174-4176 (2007).

64. Sirat, H.M.; Susanti, D.; Ahmad, F.; Takayama, H. and Kitajima, M. Amides, triterpene and flavonoids from the leaves of Melastoma malabathricum L. Journal of Natural Medicine, 64, $492-495$ (2010).

65. Dias, M.O.; Hamerski, L. and Pinto, A.C. Separação semipreparativa de a e b-amirina por cromatografia líquida de alta eficiência. Quim. Nova, 34(4), 704-706 (2011).

66. Galgon, T.; Hoke, D. and Drager, B. Identification and Quantification of Betulinic Acid. Phytochemical Analysis, 10(4), 187-190 (1999).

67. Faizi, M.A.; Saleem, R. and Irfanullah, S.B. Complete ${ }^{1} \mathrm{H}$ and ${ }^{13} \mathrm{C}$ NMR assignments of stigma5-en-3-O-b-glucoside and its acetyl derivative. Magn. Reson. Chem., 39, 399-405 (2001).

68. Aziz S. and Rehman H.U. Studies on the chemical constituents of Thymus serpyllum. Turk. J. Chem., 32, 605-614 (2008).

69. Youssef, A.M.; Abdel-Aziz, M.S. and El-Sayed, S.M. Chitosan nanocomposite films based on AgNP and Au-NP biosynthesis by Bacillus Subtilis as packaging materials. International Journal of Biological Macromolecules, 69, 185-191 (2014).

70. Popescu, M.; Velea, A. and Lorinczi, A. Biogenic production of nanoparticles. Dig. J. Nanomat. Bios., 5(4), 1035-1040 (2010).

71. Bankar, A.; Joshi, B.; Kumar, A.R. and Zinjarde, S. Banana peel extract mediated novel route for synthesis of silver nanoparticles. Colloid Surf. A Physicochem. Eng. Aspect., 368, 58-63 (2009).

72. Logeswari, P.; Silambarasan, S. and Abraham, J.J. Synthesis of silver nanoparticles using plants extract and analysis of their antimicrobial property. Saudi Chem. Soc., 19(3), 311-317 (2012).

73. Allafchian, A.R.; Zare, M.S.Z.; Jalali, S.A.H.; Hashemi, S.S. and Vahabi, M.R. Green synthesis of silver nanoparticles using Phlomis leaf extract and investigation of their antibacterial activity. $J$. Nanostruct. Chem., 6, 129-135 (2016).

74. Lakshmanan, G.; Sathiyaseelan, A.; Kalaichelvan, P.T. and Murugesan, K. Plant-mediated synthesis of silver nanoparticles using fruit extract of Cleome viscosa L.: Assessment of their antibacterial and anticancer activity. Karbala International Journal of Modern Science, 4 (1), 61-68 (2018).

75. Moustafa, H.; Darwish, N.A.; Youssef, A.M.; Reda, S. and El-Wakil, A.A. High-performance of nanoparticles and their effects on the mechanical, thermal stability and UV-shielding properties of PMMA nanocomposites. Egypt. J. Chem. 61(1), 23-32 (2018).

76. El-Nahrawy, A.M.; Ali, A.I.; Abou Hammad, A.B. and Youssef, A.M. Influences of Ag-NPs doping chitosan/calcium silicate nanocomposites for optical and antibacterial activity. International Journal of Biological Macromolecules 93, 267275 (2016)

77. Youssef, A.M.; Mohamed, S.A.; Abdel-Aziz, M.S.; Abdel-Aziz, M.E.; Turky, G. and Kamel, S. Biological studies and electrical conductivity of paper sheet based on PANI/PS/Ag-NPs nanocomposite. Carbohydrate Polymers 147 (2016) 333-343.

78. Youssef, A.M.; Youssef, M.; Ayad, D.M. and Sarhan, A.A. A Novel Approach to Prepare Poly(Vinyl Acetate)/Ag Nanocomposite for Effective Antimicrobial Coating Applications. Polymer-Plastics Technology and Engineering, 54(16), 1735-1742 (2015).

79. Ahmed, S. and Ikram, S. Synthesis of gold nanoparticles using plant extract: An overview. Nano. Res. Appl., 1, 1-64 (2015).

80. Raja, S.; Ramesh, V. and Thivaharan, V. Green bio synthesis of silver nanoparticles using Calliandra haematocephala leaf extract, their antibacterial activity and hydrogen peroxide sensing capability. Arab. J. Chem., 10, 253-261 (2017).

81. Queralt, A.; Regueiro, J.; Alvarenga, J.F.; Huelamo, M.; Leal, L. and Raventos, M. Characterization of the phenolic and antioxidant profiles of selected culinary herbs and spices: caraway, turmeric, dill, marjoram and nutmeg. Food Sci. and Tech., 35(1), 189-195 (2015).

82. Silberstein, T.; Vardi, I.; Harlev, A.; Friger, M.; Hamou, B. and Barac, T. Antioxidants and Polyphenols: Concentrations and Relation

Egypt. J. Chem. 62, No. 2 (2019) 
to Male Infertility and Treatment Success. Oxidative Medicine and Cellular Longevity, 2016, 5, ID 9140925 (2016).

83. Abdelhady, N.M. and Badr, K.A. Comparative study of phenolic content, antioxidant potentials and cytotoxic activity of the crude and green synthesized silver nanoparticles' extracts of two Phlomis species growing in Egypt. Journal of Pharmacognosy and Phytochemistry, 5(6), 377383 (2016).

84. Simionatto, E.; Bonani, V.F.L.; Morel, A.F.; Poppi, N.R.; Raposso Junior, J.L. and Stuker, C.Z. Chemical composition and evaluation of antibacterial and antioxidant activities of the essential oil of Croton urucurana Baillon (Euphorbiaceae) stem bark. J Braz. Chem. Soc., 18(5), 879-885 (2007).

85. Hung, C.Y. and Yen, G.C. Antioxidant activity of phenolic compounds isolated from Mesona procumbens Hemsl. J. Agric. Food Chem., 50(10), 2993-2997 (2002).

86. Mohd Ali, N. I.; Annegowda, H. V.; Mansor, S.M.; Ismail, S.; Ramanathan, S. and Mordi,
M.N. Phytochemical screening, antioxidant and analgesic activities of Croton argyratus ethanolic extracts. Journal of Medicinal Plants Research, 6(21), 3724-3731 (2012).

87. Compagnane, R.S.; Chavez, K.; Mateu, E.; Orsini, G.; Arvelo, F. and Suarez, A.I. Composition and Cytotoxic Activity of essential Oils from Croton matourensis and Croton micans from Venezuela. Records of Natural Products, 4(2), 101-108 (2010).

88. Singletary, K. Diet, natural products and cancer chemoprevention. J. Nutr., 130 (2S Suppl), 465S-466S (2000).

89. Suganya Devi, P.; Saravana Kumar, M. and Mohan Das, S. In vitro antiproliferative effects of anthocyanins extracted from red sorghum (Sorghum bicolor) bran on human larynx carcinoma cell line. Int. J. Pharm. Pharm. Sci., 4(4), 532-536 (2012).

90. Mohanpuria, P.; Rana, N.K. and Yadav, S.K. Biosynthesis of nanoparticles: technological concepts and future applications. J. Nanoparticle Res., 10(3), 507-517 (2008).

(Received 29/8/2018; accepted 3/10/2018)

$$
\begin{aligned}
& \text { تقييم الكفاعة المضادة للأكسدة لمستخلصات بذور نبات حب الملوك بعد دمج جزيئات الفضة } \\
& \text { النانومترية الفمية }
\end{aligned}
$$

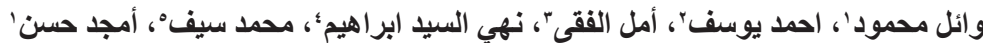

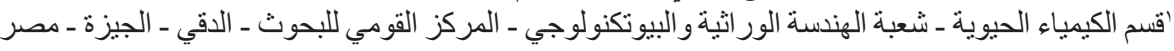

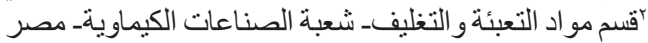

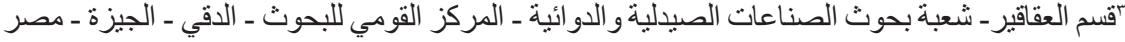

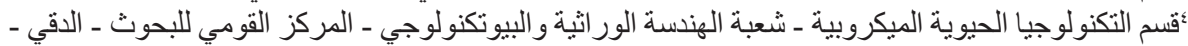

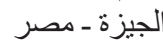

$$
\begin{aligned}
& \text { ْقسم السموم وملوثات الغذاء ـ شعبة بحوث الصناعات الغذائية ـ المركز القومي للبحوث ـ الاقي ـ الجيزة ـ مصر }
\end{aligned}
$$

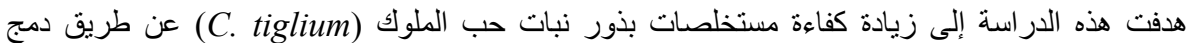

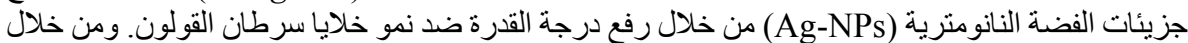

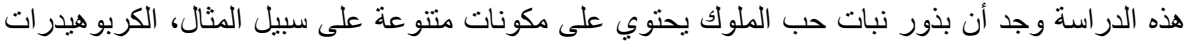

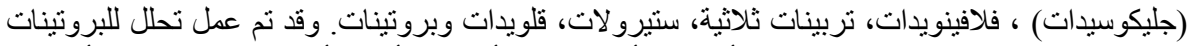

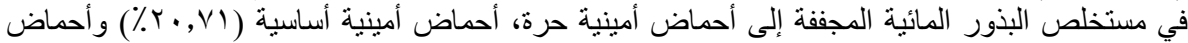

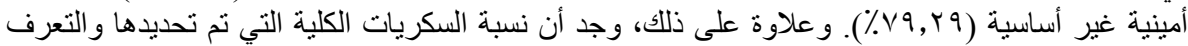

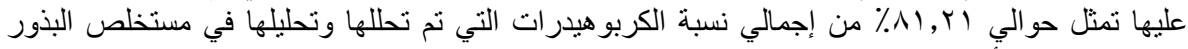

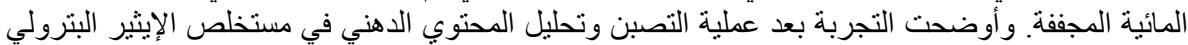

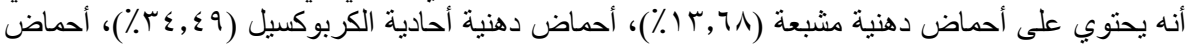

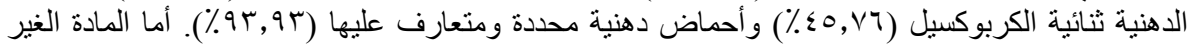

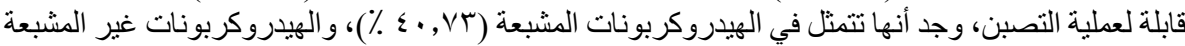

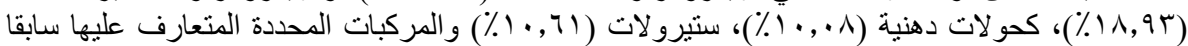

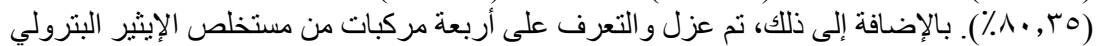

( $\beta$ sitosterol, $\alpha$-amyrin, Oleanolic acid and r-O- $\beta$-D-glucopyranosyl- $\beta$-sitosterol (daucosterol)).

وجد أن دمج جزيئات الفضة النانومترية (Ag-NPs) في أي من هذه المستخلصات لم يكن له أب سمية على المي

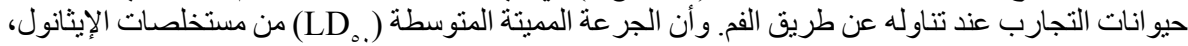

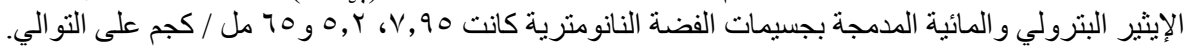

Egypt. J. Chem. 62, No. 2 (2019) 